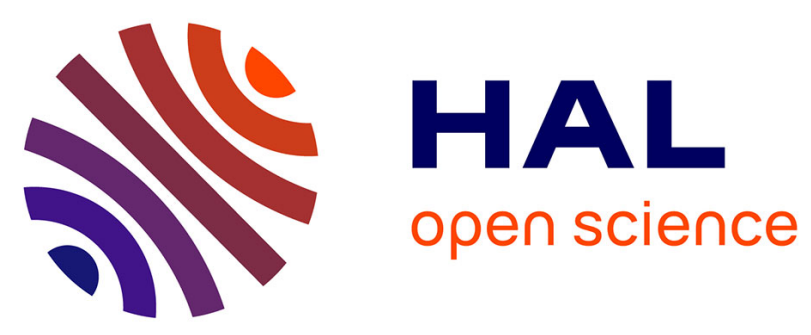

\title{
Responses of subtidal benthos of the Strait of Georgia, British Columbia, Canada to ambient sediment conditions and natural and anthropogenic depositions
}

\author{
B.J. Burd, R.W. Macdonald, S.C. Johannessen, A. van Roodselaar
}

\section{- To cite this version:}

B.J. Burd, R.W. Macdonald, S.C. Johannessen, A. van Roodselaar. Responses of subtidal benthos of the Strait of Georgia, British Columbia, Canada to ambient sediment conditions and natural and anthropogenic depositions. Marine Environmental Research, 2008, 66, 10.1016/j.marenvres.2008.08.009 . hal-00563052

\section{HAL Id: hal-00563052 \\ https://hal.science/hal-00563052}

Submitted on 4 Feb 2011

HAL is a multi-disciplinary open access archive for the deposit and dissemination of scientific research documents, whether they are published or not. The documents may come from teaching and research institutions in France or abroad, or from public or private research centers.
L'archive ouverte pluridisciplinaire HAL, est destinée au dépôt et à la diffusion de documents scientifiques de niveau recherche, publiés ou non, émanant des établissements d'enseignement et de recherche français ou étrangers, des laboratoires publics ou privés. 


\section{Accepted Manuscript}

Responses of subtidal benthos of the Strait of Georgia, British Columbia, Canada to ambient sediment conditions and natural and anthropogenic depositions

B.J. Burd, R.W. Macdonald, S.C. Johannessen, A. van Roodselaar

PII:

S0141-1136(08)00203-1

DOI:

10.1016/j.marenvres.2008.08.009

Reference:

MERE 3285

To appear in:

Marine Environmental Research

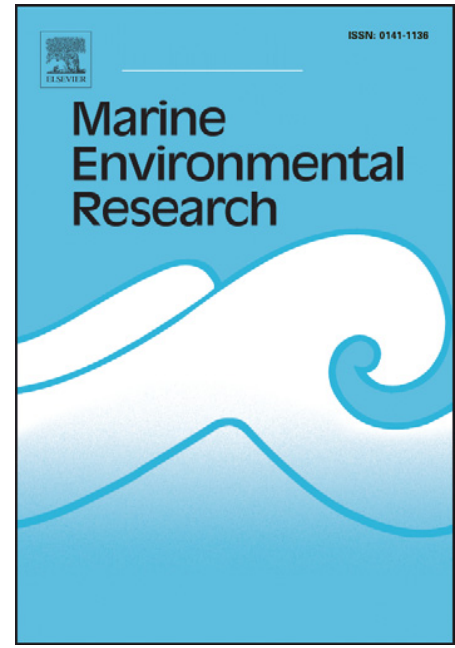

Received Date: $\quad 29$ October 2007

Revised Date: $\quad 13$ August 2008

Accepted Date: $\quad 25$ August 2008

Please cite this article as: Burd, B.J., Macdonald, R.W., Johannessen, S.C., van Roodselaar, A., Responses of subtidal benthos of the Strait of Georgia, British Columbia, Canada to ambient sediment conditions and natural and anthropogenic depositions, Marine Environmental Research (2008), doi: 10.1016/j.marenvres.2008.08.009

This is a PDF file of an unedited manuscript that has been accepted for publication. As a service to our customers we are providing this early version of the manuscript. The manuscript will undergo copyediting, typesetting, and review of the resulting proof before it is published in its final form. Please note that during the production process errors may be discovered which could affect the content, and all legal disclaimers that apply to the journal pertain. 
4 Responses of subtidal benthos of the Strait of Georgia, 5 British Columbia, Canada to ambient sediment conditions 6 and natural and anthropogenic depositions

B. J. Burd ${ }^{1}$

R. W. Macdonald ${ }^{2}$

11

S. C. Johannessen ${ }^{2}$

12

A. van Roodselaar ${ }^{3}$

13

14

15

16

1. Ecostat Research Ltd, Sidney, BC

2. Fisheries and Oceans Canada, Institute of Ocean Sciences, Sidney, BC

3. Metro Vancouver, 4330 Kingsway Burnaby, B.C., V5H 4 G8 


\section{Abstract}

19 Patterns in infaunal biota in the Strait of Georgia are explored relative to water depth, substrate

20 type, organic content of sediments and sedimentation characteristics. The analyses are based on

21 geographically-diverse grab and core data collected over a 19-year period.

23 Infaunal abundance and biomass were not predictable by sediment particle size, organic content

24 or water depth. While organic flux was a reasonable predictor of biotic factors, quality of organic

25 material, relative proportions of organic and inorganic input, and source of inputs were also

26 important in this regard. Areas with high accumulation of sediment and high organic flux rates

27 from terrestrial (riverine) sources supported the highest macro-infaunal abundance and biomass

28 found to date in the Strait of Georgia, and were dominated by bivalves. Polychaetes dominated

29 in low organic deposition conditions, and where anthropogenic organic deposition was high.

30 However, biota were severely impoverished in sediments with high organic content from marine

31 deposition, due to low fluxes and poor quality of organic material. Taxa number was related to

32 percent total nitrogen and to the ratio of organic/inorganic flux, both in background conditions

33 and where there was labile organic enrichment. Faunal communities from the Fraser River delta,

34 which experiences considerable bottom-transported riverine material, were very different in

35 composition from those that proliferate in habitats with high deposition and organic flux from the

36 water column.

38 Key words: marine benthos, sedimentation, Strait of Georgia, infaunal biomass 


\subsection{Introduction}

40 In the Pacific northwest, the two most consistently important physical factors affecting marine

41 benthic biota appear to be substrate type and water depth (Striplin, 1996; Llansó et al., 1998;

42 Striplin and Weston, 1999). In general, as water depth increases, biotic communities in coastal

43 marine areas experience reduced organic input, lower currents (and potentially lower oxygen),

44 and more stable temperature, salinity and hydrographic conditions. Globally, benthic

45 invertebrate production and production/biomass ratios tend to decrease with increasing depth

46 (Jumars and Banse, 1989; Cusson and Bourget, 2005). Ellis (1971) found, in his early review of

47 benthic fauna from the Strait of Georgia, that biomass was considerably higher in shallow areas

48 than in deeper stations within the Strait and in the surrounding fjords and channels. On open

49 continental shelves, substrates tend to get finer with water depth and organic flux from coastal

$50 \quad$ sources usually (but not always) decreases (Vinogradov and Tseitlin 1983; Shirayama 1984;

51 Vanaverbeke et al., 1997). However, this generalization can be affected by strong topographic

52 and seasonal drivers (Aller et al., 2002).

54 For British Columbia, Canada, which has a diverse and geographically extensive coastline,

55 topography and currents vary widely, such that depth, substrate type and organic loading are

56 spatially and temporally variable and complex. In the inland sea of the Strait of Georgia, there is

57 strong estuarine circulation related to seasonal input of particulates, freshwater and organic

58 carbon (OC) from the Fraser River (Johannessen et al., 2003; Hill et al., in press) and other lesser

59 freshwater sources. Over the past century, discharges from agriculture, industry and urbanized

60 regions in the southern Strait of Georgia have further complicated natural deposition. 
62 The main objective of this paper is to contribute to the understanding of natural and

63 anthropogenic factors that affect benthic biomass and productivity in the Strait of Georgia.

64 Herein, we examine recent general patterns of benthic macro-invertebrate fauna in the Strait of

65 Georgia and surrounding fjords seeking relationships with depth, substrate type and organic

66 content of sediments. These biotic patterns are then compared with organic and inorganic flux to

67 the sediments as well as the quality and composition of sediments.

$68 \quad 2.0$ Methods

\subsection{Data sources and comparisons}

70 The biotic database used herein includes abundance data for benthic invertebrate species from

71607 grab samples collected between 1988 and 2006, from areas of the Strait of Georgia and

72 surrounding fjords which are remote from anthropogenic discharges (referred to as "background"

73 areas). The database also includes 347 biotic samples from near-field areas of current

74 anthropogenic discharges, where biotic changes related to the discharge have been identified

75 (Table 1). Data from these samples will be referred to herein as "anthropogenic", to facilitate

76 comparisons with biotic distributions from background areas of the Strait. We recognize that

77 this distinction is somewhat artificial, as contamination from human activities has spread widely

78 throughout the Strait during at least the past century (Macdonald et al., 1991; Johannessen et al.,

79 2005a,b). Anthropogenic input areas for which these same data are available (Fig. 1) include:

80 Iona Island wastewater outfall (off the North Arm of the Fraser River); Lions Gate wastewater

81 outfall (in Burrard Inlet); Macaulay Point wastewater outfall (Juan de Fuca Strait). Although the

82 Macaulay Point outfall is not in the Strait of Georgia (Fig. 1), vigorous currents, high mixing,

83 sediment re-suspension and lack of confounding inputs provides an alternative habitat to 
84 examine the effects of sediment conditions on biota in an organically enriched habitat; five pulp

85 and paper mills ${ }^{1}$; and Britannia Beach mine in Howe Sound. Anthropogenic data were overlaid

86 on the background data plots to examine biotic changes relative to anthropogenic inputs.

88 The data used may be found in various technical reports and unpublished sources listed in Table

891 1; general locations of sampling programs are shown in Fig. 1. All biotic samples were collected

90 using $0.1 \mathrm{~m}^{2}$ surface area grab (Smith-McIntyre or Van Veen) with stated minimum volume

91 requirements for samples of at least 2/3 capacity. All samples were processed using a $1 \mathrm{~mm}$

92 sieve, with full taxonomic identification to species wherever possible. Detailed sampling

93 protocols and quality control information are described in the original reports. Although quality

94 control likely varied among studies, the data were sufficiently uniform in approach and method

95 of collection to provide assessment of general trends.

97 Data for sediment total organic carbon (\%TOC) were available for most samples, whereas data

98 for percentage of total nitrogen $(\% \mathrm{TN})$ were available for a limited number of samples in the

99 historical database.

100

101 For the analyses presented here, biological data from the sources indicated in Table 1 were

102 assigned consistent taxonomic codes and entered into a master database, along with ancillary

103 sediment measurements of geophysical properties and contaminant concentrations. Data on

104 hydrozoans and bryozoans, which were not included consistently in all studies, were not entered

105 into the database. Meiofauna were not considered to be representatively sampled with a $0.1 \mathrm{~mm}$

\footnotetext{
${ }^{1}$ Pulp mills included were Catalyst Paper Corporation (Powell River and Crofton), Howe Sound Pulp and Paper Ltd. (Port Mellon), Western Pulp Ltd. (Squamish), Pope and Talbot Ltd.Harmac (Nanaimo),
} 
106 mesh screen (nematodes, harpacticoid copepods) and, therefore, were not entered into the

107 database.

108

109 Summary assessment measures for infaunal benthos typically used in Pacific northwest

110 jurisdictions include taxa number and faunal abundance (Washington State Sediment

111 Management Standards: www.ecy.wa.gov/programs/tcp/smu/ sediment.html; Striplin, 1996;

112 Stiplin and Weston, 1999; GVRD, 2004). In addition, Burd (2006) found that bivalves,

113 sedentariate polychaetes, errantiate polychaetes and crustaceans are typically found in most

114 background marine sediments from coastal British Columbia. The abundance of these ubiquitous

115 faunal groups, along with total abundance and taxa number from the historical grab sample were

116 plotted against sediment depth, silt+clay (\% fines) and, where available, sediment \% TOC and

$117 \%$ TN for samples from background locations, with data from samples affected by anthropogenic

118 inputs overlaid for comparison.

120 The data include taxa abundance and taxa-specific biomass from triplicate grab samples at nine

121 locations, as part of a dedicated Ambient Monitoring Program (AMP) in the Strait of Georgia

122 (Fig. 2, Table 2, Wright et al., 2008). Methods for biological sampling and processing are

123 described by McPherson et al. (2007a, b). Eight of the AMP locations were from background

124 areas of the Strait; however, one of the AMP sample locations was placed near the largest

125 municipal outfall in the Strait to determine whether there are detectable differences in organic

126 fluxes and biological composition at this location relative to surrounding areas. Surface

127 sediment measurements of total carbon, total organic carbon (\% TOC), total inorganic carbon 
128 (\% TIC), total nitrogen (\% TN), organic carbon (OC) and inorganic carbon (IC) fluxes and stable

129 isotopes of carbon and nitrogen $\left(\delta^{13} \mathrm{C}\right.$ and $\left.\delta^{15} \mathrm{~N}\right)$ were measured from nine cores from the AMP.

131 With the exception of seasonal, or intermittent, anoxic events in two peripheral fjords (Saanich

132 Inlet and Howe Sound), bottom waters of the Strait of Georgia are always oxygenated (>2.5

$133 \mathrm{~mL} \cdot \mathrm{L}^{-1}$ ) (Masson, 2002) and support an active benthic community which mixes the surface

134 sediments through bio-turbation (Johannessen et al., 2005b). Sedimentation, and mixing rates in

135 the sediment cores were determined using excess ${ }^{210} \mathrm{~Pb}$ profiles in sediments together with

136 advective-diffusive models (Johannessen et al., 2005b). The depth of the surface mixed layer in

137 each core was determined from the ${ }^{210} \mathrm{~Pb}$ profile. Organic carbon was calculated as the difference

138 between total carbon and carbonate carbon, based on the method of Calvert et al. (1995). The

139 incident flux of $\mathrm{OC}$, the $\% \mathrm{OC}$ buried, and the \%OC oxidized were estimated from the ${ }^{210} \mathrm{~Pb}$

140 profiles of \%OC measured in the sediment cores (for methods, see Johannessen et al., 2008).

141

142 To supplement data from the AMP cores, historical core data for sedimentation rate and organic

143 flux to sediments calculated in the same manner (data sources in Table 2) were included in plots

144 of geographic distribution of sedimentation characteristics using variable-weighted VG gridding

145 in Ocean Data View (Schlitzer, 2006). Similar plots were made for sediment percent fines as

146 well as several biotic factors. Note that the extrapolated values are not valid near shore. The

147 historical data were not used for any further calculations (see below). 


\subsection{Data Analyses}

150 Gaps in the physical/chemical data from the historical database resulting from differences in the

151 suite of sediment variables measured between individual studies, prevented the application of

152 multi-factor comparisons such as multiple regression, ordination or clustering methods.

154 However, the AMP data (nine cores and grab sample locations) were examined in greater detail 155 than the historical data, to seek effects of sediment factors and sediment flux trends on biota. In

156 addition to the biotic factors examined for the historical data, total faunal biomass and abundance

157 of several other common biotic groups were analysed (gastropods, ophiuroids and holothuroids)

158 for the AMP data. Although these additional faunal groups are patchy in distribution, they can

159 contribute considerably to faunal biomass, and their presence/abundance may help explain

160 biomass trends.

162 Relationships between biotic factors and $\delta^{13} \mathrm{C}$ and $\delta^{15} \mathrm{~N}$ composition, sedimentation rates and

163 organic flux to sediments were explored initially for the AMP grab/core data using Pearson

164 correlations. In addition to the measured sediment factors, and the modeled sediment flux

165 factors, a "weighted" OC flux, which takes into account the relative lability of organic material,

166 was calculated to correlate with biotic variables. With a consistent organic source, elevations in

$167 \delta^{15} \mathrm{~N}$ have been shown to indicate increased trophic reworking in the water column due to

168 preferential use of the lighter isotope (c.f. Burd et al., 2002) and thus, are likely to indicate

169 decreased lability of organic material. Therefore, the weighted organic matter factor used to

170 compare with biotic factors was OC flux divided by $\delta^{15} \mathrm{~N}$. Although weighting using $\delta^{15} \mathrm{~N}$ is

171 based on a simplistic assumption for the Strait of Georgia, and may be confounded by the 
172 relative proportion of terrestrial versus marine organic input (Johannessen et al., 2005b), it does

173 reflect the observed differences in values for the Iona outfall deposits (very low $\delta^{15} \mathrm{~N}$ ), the Fraser

174 River deposits (moderate $\delta^{15} \mathrm{~N}$ from agricultural sediment input), and higher $\delta^{15} \mathrm{~N}$ from the

175 central deep basin (cores GVRD-1,10; Fig. 2), which is much more distant from major riverine

176 deposits.

178 No hypotheses were tested by correlation; rather, this approach helps to identify potential 179 relationships which may be explored further. Where notable correlations were evident, or non-

180 linear patterns suspected from data distribution plots, non-linear regression analyses (Zar, 1984

181 - exponential models) were used to examine variability in biotic versus sediment or sediment

182 flux factors.

\section{$183 \quad 3.0$ Results}

184 Historical samples, which ranged in substrate type from 0 to $100 \%$ fines (=silt+clay), were

185 drawn from depths ranging from 9 to $700 \mathrm{~m}$. The main basin of the Strait is uniformly silty from

186 the south end to the middle of the Strait (around Texada Island), north of which the basin

187 becomes shallower and more mixed in substrate type, with extensive erosional sand and gravel

188 beds along the coastline of eastern Vancouver Island (Burd et al., in press). Samples from the

189 deep basins of the mainland fjords (Jervis, Toba and Bute Inlets) have high percent fines (Burd

190 and Brinkhurst, 1992). The near-shore areas of the fjords tend to have more mixed sand/silt near

191 river deltas. Near-shore substrate detail can be found in the Provincial Physical Shoreline map

192 for British Columbia, (Howes et al., 1994) at URL: http:// /maps3.gov.bc.ca/imf406. 
194 Historical data showed that faunal abundance and taxa number increased with depth subtidally, 195 peaked between 60 and $80 \mathrm{~m}$, and then declined below $100 \mathrm{~m}$ in all samples (Fig.3). This trend 196 was most obvious in bivalves, and less so in polychaetes and crustaceans.

198 In the Strait of Georgia, sediment grain size appears to have limited influence on the general

199 benthic faunal indicators used herein (Fig. 4), even though it is expected to affect species

200 distributions. In background samples, total abundance was highest in mixed sediments (60-80\%

201 silt/clay), and slightly lower at both lower and higher percent fines (Fig. 4). However, samples

202 taken near the Macaulay outfall showed very high abundance in samples with low percent fines,

203 particularly with respect to polychaetes and crustaceans. Other biotic factors showed no

204 discernible trend with \% fines (Figs. 4a,b). Infaunal bivalves tended to be rare where sediment

205 fines were $<20 \%$, as in areas disturbed by current anthropogenic inputs.

207 In background samples, faunal abundance was highest where \%TOC was 1-1.5 (Fig. 5a).

208 However, faunal abundance was moderate to high at much higher \% TOC levels in some samples

209 near Macaulay outfall, as well as near the pulp and paper discharges (including some samples

210 used as reference sites during a past pulp mill monitoring program). Taxa numbers declined with

211 increasing \%TOC in background and sewage outfall samples (Fig. 5a), but were unpredictable

212 relative to \% TOC near pulp mills. Lowest taxa numbers were found in Britannia near-shore

213 sediments, with no discernible relationship to \%TOC. Notably, taxa numbers were not unusually

214 low at any location, even where \%TOC was high. Bivalves tended to be in low abundance in

215 most of the pulp and paper samples and all of the samples taken near the historical Britannia

216 mine, and, like total abundance, bivalve abundance peaked between $1 \%$ and $2 \%$ TOC (Fig. 5a). 
217 Crustaceans, errantiate and sedentariate polychaete abundance did not show any clear

218 relationship with \%TOC (Fig. 5b), except for a slight decline in crustacean abundance with

219 increasing \%TOC in background samples. Some samples from near the Macaulay outfall with

220 high \%TOC values showed enrichment by opportunistic polychaetes, such as Capitella capitata

221 complex.

222

223 Sediment $\% \mathrm{TN}$ provides a simple measure of organic composition and quality. Relatively high

224 nitrogen content implies marine or aquatic food web sources containing protein, whereas low

225 nitrogen content implies terrigenous organic matter (woody or humic material; eg. Webster and

226 Benfield, 1986). Total abundance, bivalve abundance and taxa number tended to decrease with

227 increasing \%TN (Fig. 6a), although more variable results for bivalves may have been

228 confounded by the dramatic decline in abundance below $150 \mathrm{~m}$ depth, while $\% \mathrm{TN}$ was higher in

229 deep, background samples. The declining trend with increasing \% TN was less clear for

230 crustaceans and not evident for either polychaete group (Fig. 6b) or for samples collected near

231 pulp mills.

232

233 Sediment accumulation rates (Fig. 7a) were highest immediately off the mouth of the south arm

234 of the Fraser River (GVRD-4). Sedimentation rate was too high to measure accurately in this

235 shallow core based on $\mathrm{Pb}^{210}$, and was therefore estimated (see Table 3) based on maximum

236 values in other cores and measurements from the literature. Previous work has shown

237 sedimentation rates near the Fraser delta in the range of $3-13 \mathrm{~cm} /$ year (Evoy et al., 1993; Hart et

238 al., 1998). They were also relatively high in the southern deep basin of the Strait, and tended to

239 decline with distance northward. The pattern for organic flux to sediments, based on fewer data 
240 points (Fig. 7b), was similar to that for sediment accumulation, indicating that the material

241 contributed by the Fraser River is an important source of both organic and inorganic matter to the

242 Strait.

243

244 Faunal abundance was highest overall along the bank off the Fraser River discharge, and

245 particularly near the south arm (Fig. 8a). Abundance was moderately high just outside Saanich

246 Inlet in the Satellite Channel area, in the southern-most portion of the main basin of the Strait,

247 and off the south end of Victoria in Juan de Fuca Strait. It was lowest in the deep, mainland

248 fjords along the western margin of the Strait, and in all sample locations in the northern half of

249 the Strait. Although data are limited, faunal abundance appears also to be high within the island

250 archipelago at the north end of the Strait. Bivalve abundance showed a similar pattern to overall

251 abundance (Fig. 8b), with maximum values off the bank and slope spanning the Fraser River

252 discharges. Although taxa numbers (Fig. 9) were high off the south arm of the Fraser River, they

253 were also high in several widely separated areas at the northern and southern ends of the Strait.

254 Taxa numbers were low in the central and northern portions of the main basin.

255

256 A general understanding of the sources and quality of organic matter in sediments may often be

257 gained by examining the distributions of \% TOC and \% TN, and their stable isotopic compositions

$258\left(\delta^{13} \mathrm{C}\right.$ and $\left.\delta^{15} \mathrm{~N}\right)$ (e.g. Johannessen et al., 2005b). An examination of these components for the

259 seven sediment cores from the AMP shows that the northernmost core (GVRD-1) is distinct from

260 all other cores (Fig. 10, Table 3) in having high sediment $\% \mathrm{TOC}$ and $\% \mathrm{TN}$ and high $\delta^{13} \mathrm{C}$ and

$261 \delta^{15} \mathrm{~N}$, marking it as the core most influenced by marine-derived organic matter. In contrast, low

$262 \%$ TOC and \% TN values throughout core GVRD-3, near the Iona outfall and for the station off 
263 the south arm of the Fraser River (GVRD-4), indicate strong terrigenous input due to a large 264 supply of riverine inorganic material. Recent Iona outfall deposits (after commissioning of the

265 deep-sea outfall in 1989) have a unique, low $\delta^{15} \mathrm{~N}$ signature compared with pre-outfall deposits

266 and other core locations in the Strait (Fig. 10) indicating a distinct source of organic matter at

267 that site. The isotopic composition of the sedimentary organic matter suggests that the proportion

268 of terrigenous organic matter is greatest near the Fraser River and decreases northward (see

269 Johannessen et al.( 2005b) for a discussion of the application of stable $\mathrm{C}$ and $\mathrm{N}$ isotopes to

270 discriminate sources of organic matter).

271

272 Sediment accumulation rate, OC flux, inorganic flux and buried OC flux were highly inter-

273 correlated $\left(r^{2}=0.98\right.$ not shown). These four factors did not always correlate consistently with a

274 given biotic factor, but consistent patterns are notable. For example, biomass, gastropod and

275 crustacean abundance correlated positively with all four of the aforementioned factors. In

276 contrast, the ratio of polychaete abundance to total abundance correlated negatively with the four

277 sediment factors, as well as with oxidized OC flux.

278

279 Total abundance, biomass, ophiuroid, bivalve, gastropod and sedentariate polychaete abundance

280 were moderately to highly positively correlated with total flux, OC flux, OC flux weighted by

$281 \delta^{15} \mathrm{~N}$, inorganic and buried OC fluxes. Oxidized OC flux, which would be expected to be a good

282 indicator of biological activity in sediments, was not strongly positively correlated with any

283 biological factor. 
285 The percent carbonate in surface sediments showed moderate to strong positive correlation with

286 a range of biotic factors, including taxa number, total abundance, abundance of ophiuroids,

287 bivalves, errantiate and sedentariate polychaetes. However, the proportion of both types of

288 polychaetes showed a low negative correlation with \%carbonate. A very similar pattern of

289 positive and negative correlations was evident between these biotic factors and organic flux

290 weighted by $\delta^{15} \mathrm{~N}$. Percent bivalve abundance was strongly negatively correlated with $\delta^{15} \mathrm{~N}$, and

$291 \quad \delta^{13} \mathrm{C}$.

292

293 The number of taxa was most strongly negatively correlated with organic/inorganic flux ratio,

$294 \% \mathrm{TN}$ and \%TOC. A plot of taxa number vs. organic/inorganic flux showed a negative

295 exponential relationship $\left(r^{2},=0.87\right.$, Fig. 11). The best fit line for this function was superimposed

296 on the scatterplot for taxa number versus \% TN for combined historical and AMP data from all

297 background and anthropogenic sites (Fig. 11), which also showed an exponential correlation

$298\left(\mathrm{r}^{2}=0.76\right)$. Both of these regressions were highly significant $(\mathrm{P}<0.0001)$. The two functions show

299 very similar shapes and slopes. Only the data for samples near pulp mills showed unusual

300 deviations from the primary trend.

301

302 The highest faunal biomass was found in cores GVRD-4 and -6, followed by core GVRD-5 (Fig.

303 12). Total biomass was positively exponentially correlated with sediment accumulation rate

304 (Table 4), OC flux, inorganic flux, and buried OC flux. The buried OC flux explained $84 \%$ of

305 variance in faunal biomass (Fig. 12). Biotic factors did not show any correlation with AVS

306 concentration (Table 4), and do not show any relationship to biotic factors in the historical

307 database (not shown). 


\section{4.0 Discussion}

\subsection{Geographic distribution of sedimentation and biota}

312 The highest sediment accumulation rates and organic fluxes occur along the eastern margin of

313 the Strait, off the Fraser River, with the nearby station GVRD-4 having the highest estimated

314 fluxes for this study (Hill et al., in press). Sandy silt from the Fraser River is transported

315 outward from the delta along the bottom northward and downslope (Pharo and Barnes, 1976;

316 Evoy et al., 1993; Hart et al., 1998; Hodgins and Hodgins, 2000;

317 http://gsc.nrcan.gc.ca/marine/gbgi/proj_surf_e.php, 2006; Hill et al., in press). The organic and 318 inorganic sediments from the Fraser River dominate the input to sediments near the Fraser delta

319 (Hodgins and Hodgins, 2000; Hill et al., in press). The Iona Island wastewater outfall, which is

320 the largest volume marine sewage discharge in British Columbia ( $145 \times 10^{6} \mathrm{~m}^{3} / \mathrm{yr}$ water), is

321 located about $10 \mathrm{~km} \mathrm{~N}$ of the south arm along the Fraser River foreshore, and discharges through

322 diffusers at 60-90 m depth (Fig. 1). Model results (Hodgins and Hodgins, 2000) indicate that the

323 maximum particle deposition from the Iona outfall $\left(\sim 0.3 \mathrm{gcm}^{-2} \mathrm{yr}^{-1}\right)$ occurs within the first $\mathrm{km}$

324 north of the outfall. The sedimentation rate estimated from a core collected at that location

325 (GVRD-3) is $1.34 \mathrm{gcm}^{-2} \mathrm{yr}^{-1}$. Therefore, about $25 \%$ of the total sedimentation just north of the

326 Iona outfall could be accounted for by municipal outfall discharge, with the other $75 \%$ coming

327 from the Fraser River. This estimate is relatively close to that noted by Macdonald et al. (in

328 press), using $\mathrm{Zn} / \mathrm{Cd}$ ratios in effluent and sediments. The suspended particles from the outfall

329 contain about 30\% TOC (S. Bertold, Metro Vancouver, pers. comm.). Therefore, with the $75 \%$

330 dilution from the Fraser River particulates, which contain <1\% TOC (Johannessen et al., 2003), 
331 the sediment \%TOC just north of the outfall should be about 7-8\%. In fact, the sediments near

332 the outfall are within background levels for \% TOC content $(<1.5 \%)$. There are several possible

333 explanations for the discrepancy; 1) the model overestimates sedimentation to the bottom from

334 the outfall; 2) most of the sedimenting organic material is rapidly broken down within sediments

335 (supported by high oxidation rates in the current study), or; 3) most of the organic material from

336 the outfall does not reach bottom due to biogenic uptake or degradation in the water column.

338 Faunal abundance and biomass were highest in the Fraser River frontal area, suggesting that

339 these are highly productive sediments. Bivalves dominated the fauna in this area (40-60\% of

340 abundance and biomass - Fig. 8 b and Burd, 2003a; McPherson et al., 2007a) more than

341 anywhere else in the Strait. Other authors have noted dominance by infaunal bivalves in marine

342 sediments subject to terrigenous inflow in Arctic and subarctic coastal areas (Thorson, 1957;

343 Wlodarska-Kowalczuk and Pearson, 2004; Wlodarska-Kowalczuk et al., 2007 and references

344 therein). Wlodarska-Kowalczuk (2007) and Wlodarska-Kowalczuk et al. (2004, 2005, 2007)

345 suggested that sediment stability played a major role in structuring faunal type and productivity,

346 with the consequence that the dominant benthic organisms were bivalves in intermediate

347 deposition areas, opportunistic (recolonizing) polychaetes in very high deposition areas (up to

$34836.5 \mathrm{~g} / \mathrm{cm}^{2} / \mathrm{a}$ ) with slope instability, and a variety of primarily tube-building polychaetes in low

349 deposition, deep areas. They found that faunal biomass was highest in areas of intermediate

350 deposition, falling off in both the lower and higher deposition areas. Results from the current

351 study support this general pattern. For example, polychaetes tended to be the dominant fauna in

352 areas of the Strait where sedimentation and organic flux were low. Although unstable areas with

353 extremely high deposition were not sampled in this study, the location with the highest 
354 deposition (GVRD-4, near the south arm of the Fraser River) has shown a recent increase in

355 dominance by small, rapidly recolonizing polychaetes where bivalves were much more dominant

356 previously (McPherson et al., 2007a). This location could have experienced an increase in

357 particulate deposition from the river in recent years.

359 In the southern Strait (core GVRD $6-187 \mathrm{~m}$ deep), fine sand and silt suggest deposition from the

360 river either directly or through resuspension, and/or erosion of material from the southern Gulf

361 Islands via energetic tidal mixing and currents that transport material northward via Haro Strait

362 (Masson and Cummins, 2004; Johannessen et al., 2006). Particulate organic matter, enhanced

363 bacterioplankton production (Albright, 1983) and inorganic particles in the Fraser River plume

364 contribute to the high flux. Biotic abundance and biomass were relatively high at station GVRD-

365 6. The major difference in biota between the delta/slope area and the deeper, southern basin of

366 the Strait, was that the latter had lower overall abundance, a lower proportion of bivalves, and

367 greater dominance by crustaceans and holothurians. However, total biomass in the two areas was

368 similar.

370 Sedimentation, organic flux, infaunal abundance, biomass and taxa number were all lowest in the

371 basin north of Texada Island (GVRD-1, GVRD-10). This is not surprising, since evidence from

372 sediment trap (Johannessen et al., 2005b) and multi-beam (Hill et al., this issue) studies indicate

373 a minimal influence of Fraser River particles in the north-central and northern Strait. Long-term

374 monitoring shows that the total water column primary production is greater in the northern Strait

375 than it is in the southern basin (D. Masson, Fisheries and Oceans Canada, personal

376 communication, 2008), and particles that sink in this area have a higher organic content than 
377 elsewhere in the Strait (Johannessen et al., 2006). The flux of these organic-rich particles seems

378 to peak in late spring, after the main spring bloom. Consequently, the organic matter in the

379 sediments of the northern Strait is mostly marine (Johannessen et al., 2005b), along with some

380 terrigenous organic matter added by pulp mills within the northern half of the Strait (Macdonald

381 et al., 1991).

383 Sedimentation rates for the inlets and fjords seem to be relatively low compared with the Fraser

384 River delta/slope area, based on historical core data for Burrard Inlet and Howe Sound (Table 2).

385 In outer Burrard Inlet, sediment accumulation rates are considerably lower than along the Fraser

386 River delta/slope, whereas faunal abundance and biomass are only moderately lower (McPherson

387 et al., 2007b). Bivalves predominate in outer Burrard Inlet, as they do along the Fraser River

388 foreshore (Je et al., 2003; McPherson et al., 2007b), suggesting moderate deposition rates.

389 Carbon/nitrogen ratios and stable isotopes suggest that sedimenting material in the outer Burrard

390 Inlet comes primarily from the Fraser River (Boyd et al., 1997), however numerous types of

391 anthropogenic discharge contribute unknown quantities of particulate material as well. High

392 flocculent content in the water column observed near the First Narrows bridge (CORI, 2002)

393 suggests that the strong currents re-suspend material from the bottom, reducing the predictability

394 of biotic abundance and biomass based on core-derived flux rates (McPherson et al., 2007b).

396 The sediment accumulation rate is lower in the main basin of Howe Sound than in outer Burrard

397 Inlet (Johannessen et al., 2003), as is faunal abundance. However, confounding factors in Howe

398 Sound undoubtedly affect biotic conditions. These include discharges from two pulp mills, acid

399 mine drainage that continues to leak from an abandoned copper mine (Britannia), and 
400 intermittent stagnation in the deep basin water behind the sill (Levings et al., 1983; Stucchi,

401 2006).

402

403 Sediments in the deep basin of Jervis Inlet (Burd and Brinkhurst, 1992) are composed of

404 uniformly fine silt ( $98 \%$ ), similar to those in the deepest deposition areas of the main basin of

405 the Strait. This suggests that particulate flux to these sediments is low. Total faunal abundance

406 was lower in samples from the deep basin of Jervis Inlet than in Howe Sound or outer Burrard

407 Inlet.

408

409 Aside from a few measurements from just north of Saanich Inlet (Burd, et al., 2000; Burd and

410 Glaholt, 2000; Seacology, 2001; Glaholt et al. 2002), and from several pulp mill areas, there are

411 few biological or core data available from the near-shore areas along the western margin of the

412 Strait, so fluxes cannot be compared for this region. In Saanich Inlet, historical organic flux data

413 to sediments at the CEPEX site just inside the sill (Whitney and Wong, 1984) suggest rates

414 intermediate between those found at the Iona outfall station (GVRD-3) and at the station outside

415 Burrard Inlet (GVRD-2). However, bottom water hypoxia is the most important factor

416 structuring benthic communities in Saanich Inlet (Tunnicliffe 1981; Burd and Brinkhurst, 1984).

\subsection{Predictability of biotic patterns from ambient and sedimentation conditions}

420 Percent fines was not a major factor structuring the biotic indicators measured during this study

421 (see also Levin and Gage, 1998), although it is expected to have a profound effect on community

422 composition and balance of feeding types (Bernard, 1978; Levin and Gage, 1998). The current

423 study shows that biotic declines tended to occur below $100 \mathrm{~m}$ depth, and even more dramatically 
424 below $300 \mathrm{~m}$ depth. This decline with depth, which has also been observed in other high-latitude

425 seas from the continental margin (about $200 \mathrm{~m}$ ) to abyssal depths (3000 m - Levin and Gage,

426 1998; Wlodarska-Kowalczuk et al., 2004), parallels the observed decline in organic input with

427 depth (Suess, 1980; Vinogradov and Tseitlin, 1983; Shirayama, 1984; Bishop, 1989;

428 Vanaverbeke et al., 1997).

430 The data from the current study clearly illustrate that sediment organic content is a poor predictor

431 of benthic macro-infaunal abundance and biomass in the Strait of Georgia. Hyland et al. (2005)

432 suggested that infauna increase in abundance and taxa number as organic content increases, up to 433 a threshold, beyond which they decline (as per Pearson and Rosenberg, 1978). This pattern can

434 be seen near the Macaulay Point outfall south of Greater Victoria (Fig. 1) (Burd, 2003b).

435 However, organic enrichment gradients cannot always be identified by sediment organic content.

436 For example, organic loading from the Iona outfall in the Strait of Georgia is swamped by a

437 large, primarily inorganic deposition from the Fraser River (Hodgins and Hodgins, 2000; Yunker

438 and Macdonald, 2003; McPherson et al., 2007a), so that sediment organic content remains within

439 background ranges along the delta. However, there is evidence of elevated sulphides in

440 sediments and enrichment-related faunal changes near the outfall (Burd, 2003a; McPherson et

441 al., 2007a).

442

443 A further example of the unexpected relationship between sediment organic matter and biotic

444 conditions in the Strait of Georgia was evident in the samples taken from Texada Island

445 northward. Unusually high sediment OC, nitrogen and $\delta^{15} \mathrm{~N}$ in the cores (GVRD-1 and 10), and 
446 notably impoverished biota suggest that sedimenting marine organic material is recalcitrant in

447 that region of the Strait and contains little of nutritional value by the time it reaches the bottom.

449 Organic flux to sediments is a much better indicator of biotic abundance and biomass than 450 organic content of sediments. Similarly, Rowe et al. (1991) pointed out that POC flux to

451 sediments was a much better estimator of infaunal biomass in the western North Atlantic than

452 sediment detrital organic content, and Grebmeier et al. (1988) showed benthic infaunal biomass

453 to be coupled with flux of organic matter to the seabed in the northern Bering and Chukchi Seas.

454 Johnson et al. (2007) also showed that modeled vertical POC flux from surface satellite color

455 imagery accounted for about $2 / 3$ of the variance in benthic standing stock of macrobenthos in the 456 western North Atlantic.

458 The quality of organic matter, including contaminant content, in structuring marine infaunal 459 growth and production has not been extensively studied but appears to an important modifier of 460 the aforementioned POC/biotic relationships (Gunnarsson et al., 1999; Aller et al., 2002;

461 Danovaro, 2003). A modified measure of organic flux, which took into account the relative age 462 and lability of organic material, was a better predictor of many biotic factors than unweighted 463 organic flux (Table 4). However, this was not true for total biomass, because the station just 464 north of the Iona outfall skewed the relationship. Despite relatively high sedimentation rates and 465 organic flux at this location (GVRD -3), biomass was low, due to the loss of ophiuroids and the 466 reduction in bivalve abundance. Bivalve abundance is thought to be relatively low near the 467 outfall because of sulphide toxicity from the organic enrichment of sediments (Burd, 2003a; 468 McPherson et al., 2007a; GVRD, 2004). A regression of total biomass on $\log _{10}$ weighted organic 
469 flux, calculated without the outfall station, explains $82 \%\left(\mathrm{r}^{2}\right)$ of the variance in biomass. In the

470 Strait of Georgia, this suggests that infaunal biomass can be well predicted by flux and quality of

471 organic matter to sediments under background conditions of sedimentation, but that sediment

472 toxicity may override the relationship in areas of anthropogenic inputs of organic matter.

473

474 In the Strait of Georgia, river-borne deposits mixed with marine flux appear to provide a more

475 productive substrate for infauna than do marine deposits alone. Many of the abundance factors

476 measured in this study are related to total flux as well as to \% carbonates. A high concentration

477 of carbonate in sediments usually indicates river-borne sediments, although over the small scale

478 of the central Strait of Georgia, the carbonate distribution is patchy (Gordon, 1997), so that

479 interpretation is not clear in this case.

481 Taxa number was poorly predicted by organic flux and quality. Taxa numbers in background

482 conditions and near sewage outfalls were strongly negatively correlated with \% TOC, \% TN and

483 the ratio of OC to inorganic flux to sediments (Table 4). These sediment factors were also

484 strongly positively inter-correlated. This is not surprising, since the diversity of benthic marine

485 faunal types is theoretically related to the diversity of substrate habitats and habitat stability

486 within a given area (Gray et al., 2002). Based on results from extensive trawl surveys in the

487 Strait of Georgia, Bernard (1978) suggested that the more consistently fine substrates (without

488 terrigenous debris, shell hash, or a variety of particle sizes) had fewer habitat niches available.

489 Therefore, \% TN and relative organic/inorganic composition of sediments appear to be useful

490 surrogates for measuring habitat heterogeneity, and thus predicting taxa number. 
492 However, taxa number did not show any pattern with sediment organic content near pulp mills.

493 Focused studies outside the government monitoring programs near several of the pulp mills have 494 shown finer-scale bio-diversity impacts related to mill effluents (Jones and Ellis, 1975; Pearson

4951980 for review; Ostrovsky, 1987), but these patterns are not evident in the federal

496 Environmental Effects Monitoring program data for pulp and paper mills URL:

497 (ec.gc.ca/eem/english/PulpPaper/default.cfm). In addition, the Britannia mine near-field

498 samples had uniformly low taxa numbers over a range of \% TOC levels (\% TN not measured),

499 possibly due to metal toxicity (Hagan et al., 2004; G3, 2003). This pattern of reduced taxa

500 number but not abundance in the area of historical tailings deposition near the mine was also

501 noted 12 years after the mine closed (Ellis and Hoover, 1990).

502

503 Of the major taxonomic groups that are typically found in infaunal samples in British Columbia

504 (bivalves, errantiate and sedentariate polychaetes, crustaceans), the bivalves in the present study

505 tended to show the clearest responses to ambient and sedimentation gradients, although the

506 reasons for these responses were not always clear. The relative rarity of infaunal bivalves at

507 depths greater than 150-200 m in the Strait of Georgia has been observed coast-wide (Burd,

508 2006). Bivalve percent abundance was very strongly negatively correlated with $\delta^{15} \mathrm{~N}$ and $\delta^{13} \mathrm{C}$,

509 which we suggest is indicative of poor food quality. Since bivalves selectively ingest preferred

510 organic material and reject the rest as pseudo-faeces (Taghon, 1982; Newell and Jordan, 1983;

511 Macdonald and Ward, 1994; Bacon et al., 1998), there may simply not be enough food of

512 acceptable quality for infaunal bivalves in the deeper areas of the Strait and fjords (or possibly in

513 areas with very low sediment percent fines). This is supported by the relatively high correlation

514 between bivalve abundance and organic flux weighted by $\delta^{15} \mathrm{~N}$. 
516 The low bivalve abundance in the shallow areas may be an artifact of the limited number of

517 shallow samples included in the database. For example, bivalve abundance was uniformly low

518 in samples from 5 to $20 \mathrm{~m}$ depth near the Britannia mine site. Bivalves are known to bio-

519 accumulate metals in their tissues, and a study of intertidal mussels has suggested toxicity

520 responses in proximity to the Britannia mine drainage (Grout and Levings, 2001). A benthic

521 study in Boundary Bay near the Washington border showed that infaunal bivalves were patchily

522 abundant in shallow subtidal stations, but that substrate conditions (such as eel-grass beds) could

523 potentially inhibit bivalve burrowing (Burd, 1992). Such erratic results suggest that more

524 detailed sampling of shallow subtidal areas in the Strait of Georgia is required to understand

525 biotic conditions relative to sedimentation.

527 Bivalves were the only group clearly depressed in samples taken near pulp and paper mills,

528 suggesting that pulp mill deposits are not ideal for infaunal bivalve growth. This may be related

529 to difficulty in burrowing through the fibrous organic material, or the low food quality of organic

530 material in sediments. Several earlier studies of the impacts of wood waste in the Strait of

531 Georgia tend to support the hypothesis that burrowing is impeded by wood fibre debris (Conlan,

532 1977; Conlan and Ellis, 1979; Ostrovsky, 1987).

\section{$533 \quad 5.0$ Conclusions}

535 Infaunal abundance and biomass in the Strait of Georgia cannot be readily predicted by static

536 measurements of sediment particle size, organic content or water depth, because these measures

537 do not take into account the rate or quality of organic input. Organic flux and quality are good 
538 predictors of biotic abundance and biomass, particularly when outliers affected by sediment

539 toxicity related to organic enrichment are considered separately. Higher deposition rates from

540 terrestrial sources typically translate to higher overall labile organic input, supporting a high

541 macro-faunal abundance and biomass, as well as dominance by infaunal bivalves. Relative

542 proportions of organic and inorganic flux, as well as \% carbonate, were also important to biota,

543 suggesting that organic matter and other factors in riverine input support productive benthic

544 assemblages in the Strait of Georgia. It is clear from this study that organic and inorganic flux to

545 sediments and the type of substrate influence infaunal production, and that all of these factors

546 need to be included when modeling biological impacts related to organic deposition (Cromey et

547 al., 1998).

549 Predictions of faunal abundance and biomass based on organic flux and quality to sediments

550 must be approached with caution in complex hydrographic/input areas such as Burrard Inlet, and

551 in fjords where confounding factors such as basin stagnation are primary drivers of benthic

552 productivity. In addition, shallow subtidal areas in the Strait of Georgia have not been

553 adequately studied in terms of infaunal or sedimentation patterns.

555 Taxa number can be well predicted by $\% \mathrm{TN}$ or rate of organic/inorganic flux under background 556 conditions, as well as in situations of labile organic enrichment (Iona and Lions Gate outfalls).

557 Taxa number is much less predictable near pulp mills and in areas receiving acid mine drainage.

559 The composition of the benthic fauna varies dramatically throughout the Strait, as do

560 sedimentation dynamics. Fauna that are best suited to continuous bottom transport of material 
561 northward and downslope from the Fraser River delta are clearly not the same as those best

562 suited to conditions with high, finer particulate deposition from the water column.

563

\section{$564 \quad 6.0$ Acknowledgements}

566 We appreciate the assistance of Cindy Wright, Fisheries and Oceans Canada (Institute of Ocean

567 Sciences), for technical support with figures, data and formatting. Data from many sources were

568 collated using a systematic taxonomic coding designed by Biologica Environmental Services

569 Ltd, Victoria, BC. Funding for this work was provided by a collaborative agreement among

570 Metro Vancouver (formerly the Greater Vancouver Regional District) Fisheries and Oceans

571 Canada, and Natural Resources Canada. 


\section{$573 \quad 7.0$ References}

574

Albright, L.J., 1983. Influence of river-ocean plumes upon bacterioplankton production of the Strait of Georgia, British Columbia. Marine Ecology Progress Series 12, 107-113.

Aller, J.Y., Aller, R.C., Green, M.A., 2002. Benthic faunal assemblages and carbon supply along the continental shelf/shelf break-slope off Cape Hatteras, North Carolina. Deep-Sea Research II 49, 4599-4625.

Bacon, G.S., MacDonald, B.A.,Ward, J.E., 1998. Physiological responses of infaunal (Mya arenaria) and epifaunal (Placopecten magellancius) bivalves to variations in the concentration and quality of suspended particles. I. Feeding activity and selection. Journal of Experimental Marine Biology and Ecology 219, 105-125.

Bailey, H.C., McPherson, C.A., Hodgins, D.O., Fanning, L., Paine, M.D., Burd, B.J., Macdonald, V., Brooks, G.C., Chen, F., Brand, D.,Raverty, S., 2003. Iona Deep-Sea Outfall, 2001 Environmental Monitoring Program. Final Report, Prepared for the Greater Vancouver Regional District by EVS Environmental Consultants Ltd., North Vanouver BC., Burnaby, B.C., 344 pp. + appendices.

Barnes, P.A.G., 2007. Shellfish Culture and Particulate Matter Production and Cycling: Final Data Report. BC Aquaculture Research \& Development Committee. Project AE 02.0302.01, 257 pp. + App.

Bernard, F.R., 1978. British Columbia Faunistic Survey: Subtidal and Deep-water Megafauna of the Strait of Georgia. Canadian Fisheries and Marine Services Manuscript Report 1488, $41 \mathrm{pp}$. 
Bishop, J.K.B., 1989. Regional extremes in particulate matter composition and flux: effects on the chemistry of the ocean interior, in: W.H. Berger, V.S. Smetacek and G. Wefer (Ed.), Productivity of the Ocean: Present and Past. J. Wiley \& Sons Limited, Dahlem, pp. 117137.

Boyd, J., Macdonald, R., Paton, D.W., Hutton, K., Baumann, J., Bertold, S., Moore, B., 1997. Burrard Inlet Sediment Core Contaminant Profiles, A Report Prepared for the Burrard Inlet Environmental Action Program, Vancouver, BC., 15 pp. + appendices.

Burd, B.J., 1992. Qualitative and quantitative studies of benthic infaunal communities in British Columbia coastal waters, Department of Biology, University of Victoria. Ph.D., 375 pp.

Burd, B.J., 2003a. Ecological Significance of IONA 2000-2002 Monitoring Results for Benthic Infaunal Communities, in: Greater Vancouver Regional District (Ed.), Greater Vancouver Regional District, Cautions, Warnings \& Triggers: A Process for Protection of the Receiving Environment. Appendices: Technical Reports and Monitoring Programs, Prepared for the Ministry of Environment Land and Air Protection, BC, pp. Diii-D70.

Burd, B.J., 2003b. Ecological Effects Related to the Outfall Particulates Discharge Determined from the Macaulay Point Monitoring Program 1994-2001, Report to Capital Regional District, Victoria, British Columbia.

Burd, B., 2006. Analysis of Historic Benthic Biological Data to Determine Validity of the Ecological Threshold Concept for Soft Substrate Impacts Related to Coastal BC Fish Farm Discharges, Report to British Columbia Ministry of Environment, Nanaimo, BC.

Burd, B.J. Barnes, P.A.G., Wright, C.A., Thomson, R.E., in press. A review of subtidal benthic habitats and invertebrate biota of the Strait of Georgia, British Columbia. Marine Environmental Research. 
618 Burd, B.J.,Brinhurst, R.O., 1984. The distribution of the galatheid crab Munida quadrispina 619 (Benedict 1902) in relation to oxygen concentrations in British Columbia fjords. Journal 620 of Experimental Marine Biology and Ecology 81, 1-20.

621 Burd, B.J., Brinkhurst, R.O., 1992. Benthic infaunal surveys of British Columbia fjords, 1988 to 1990. Canadian Data Report of Hydrography and Ocean Sciences 114, 37 pp.

623 Burd, B.J., Glaholt, R., 2000. Survey of benthic infauna at the Manley Creek landfall site at Boatswain Bank, British Columbia. Ecostat Research Ltd. and Tera Environmental

Burd, B.J., Thomson, R.E., Calvert, S.E., 2002. Isotopic composition of hydrothermal epiplume zooplankton: evidence of enhanced carbon recycling in the water column. Deep-Sea Research Part I Oceanographic Research Papers 749, 1877-1900.

Burd, B.J., Glaholt, R., Macdonald, V., 2000. Reconnaissance Level Baseline Survey of Benthic Infaunal communities at Ecological Reserve 67 and Adjacent Satellite Channel, June 4, 2000. Georgia Strait Crossing Pipeline Ltd., 14 pp.+ appendices.

Calvert, S.E., Pedersen, T.F., Naidu, P.D., Von Strackelberg, U., 1995. On the organic carbon maximum on the continental slope of the eastern Arabian Sea. Journal of Marine Research 53, 269-296.

Capital Regional District (CRD), 2003. Macaulay and Clover Point Wastewater and Marine Environment Program 2002 Annual Report, Capital Regional District, Environmental Services Department, Victoria, BC, Canada.

Capital Regional District (CRD), 2004. Macaulay and Clover Point Wastewater and Marine Environment Program 2003 Annual Report, Capital Regional District, Environmental Services Department, Victoria, BC, Canada. 
641 Capital Regional District (CRD), 2005. Macaulay and Clover Point Wastewater and Marine

642 Environment Program 2004 Annual Report, Capital Regional District, Environmental

643 Services Department, Victoria, BC, Canada.

644 Coastal and Ocean Resources Incorporated (CORI), 2002. Lions Gate ROV Far-Field Imaging

645 Survey, Prepared for the GVRD, Burnaby, BC by Coastal and Ocean Resources

646 Incorporated, Sidney, BC, 30 pp. + appendices.

647 Conlan, K., 1977. The effects of wood deposition from a coastal log handling operation on

648 benthos of a shallow sand bed in Saanich Inlet, British Columbia. M.Sc., University of

$649 \quad$ Victoria, Victoria, B.C.

650 Conlan, K.E., Ellis, D.V., 1979. Effects of wood waste on sand-bed benthos. Marine Pollution

$651 \quad$ Bulletin 10, 262-267.

652 Cromey, C.J., Black, K.D., Edwards, A., Jack, I.A., 1998. Modelling the deposition and

653 biological effects of organic carbon from marine sewage discharges. Estuarine, Coastal

$654 \quad$ and Shelf Science 47, 295-308.

655 Cusson, M., Bourget, E., 2005. Global patterns of macroinvertebrate production in marine 656 benthic habitats. Marine Ecology Progress Series 297, 1-14.

657 Danovaro, R., 2003. Organic inputs and ecosystem efficiency in the deep Mediterranean sea. $658 \quad$ Chemistry and Ecology 19, 391-398.

659 Ellis, D.V., 1970. A review of marine infaunal community studies in the Strait of Georgia and $660 \quad$ adjacent inlets. Syesis 4, 3-9.

661 Ellis, D.V., Hoover, P.M., 1990. Benthos on tailings beds from an abandoned coastal mine.

662 Marine Pollution Bulletin 21, 477-480. 
663 Evoy, R.W., Moslow, T.F., Patterson, R.T., Luternauer, J.L., 1993. Patterns and variability in 664 sediment accumulation rates, Fraser River delta foreslope, British Columbia, Canada. 665 Geo-Marine Letters 13, 212-218.

666 G3 Consulting Ltd., 2003. Britannia Beach Subtidal Sampling Programs: Final Report, Prepared 667 for Environment Canada, North Vancouver, BC, 62 pp.

668 Glaholt, R., Burd, B., Haight, R. 2002. Preliminary report on the environmental effects of a 669 marine pipeline on nearby soft bottom benthic infaunal communities - Bazan Bay,

673 Grebmeier, J.M., McRoy, C.P., Feder, H.M., 1988. Pelagic-benthic coupling on the shelf of the northern Bering and Chukchi Seas. I. Food supply source and benthic biomass. Marine

678 Grout, J.A., Levings, C.D., 2001. Effects of acid mine drainage from an abandoned copper mine, Ecology Progress Series 48, 57-67.

Gordon, K., 1997. Sedimentary Tracers of Sewage Inputs to the Southern Strait of Georgia.

Gunnarsson, J.S., Granberg, M.E., Nilsson, H.C., Rosenberg, R., Hellman, B., 1999. Influence of sediment organic matter quality on growth and PCB bioavailability in Amphiura filiformis (Echinodermata). Environmental Toxicology and Chemistry 18, 1534-1543. Britannica Mines, Howe Sound, British Columbia, Canada on transplanted blue mussels (Mytilus edulis). Marine Environmental Research 51, 265-288. University of British Columbia, M.Sc., 217 pp. 
Land and Air Protection, January, 2004, Greater Vancouver Regional District, Burnaby, B.C., 170 pp. + appendices.

Hagan, M., McCandless, R., More, B., Colodey, A., 2004. Nearshore contaminated sediment investigations at Britannia Beach, British Columbia, Environment Canada Pacific and

Hodgins, D.O., Hodgins, S.L.M., 2000. A re-evaluation of Iona effluent solids deposition based on sediment grain size characteristics, in: Greater Vancouver Regional District (Ed.), Development of a Receiving Environment Monitoring Approach to Liquid Waste Management, Progress Workshop 2 December 6, 2000. Support Material Part 2 of 3 Iona WWTP Receiving Environment, Draft Technical Report, GVRD, Burnaby, BC, pp. 1-1 $1-24$.

Howes, D.E., Harper, J.R., Owens, E., 1994. British Columbia Physical Shore-zone, A Report for the British Columbia Resource Inventory Committee, Victoria, B.C., 84 pp.

Hyland, J., TBalthis, L., Karakassis, I., Magni, P., Petrov, A., Shine, J., Verstergaard, O., Warwick, R., 2005. Organic carbon content of sediments as an indicator of stress in marine benthos. Marine Ecology Progress Series 295, 91-103. 
Je, J.-G., Belan, T., Levings, C., Koo, B.J., 2003. Changes in benthic communities along a presumed pollution gradient in Vancouver Harbour. Marine Environmental Research 57, $121-135$.

Johannessen, S.C., Macdonald, R.W., Paton, D.W., 2003. A sediment and organic carbon budget for the greater Strait of Georgia. Estuarine, Coastal and Shelf Science 56, 845-860.

714 Johannessen, S.C., Masson, D., Macdonald, R.W., 2006. Distribution and cycling of suspended particles inferred from transmissivity in the Strait of Georgia, Haro Strait and Juan de

Johannessen, S.C., Macdonald, R.W., Eek, M.K., 2005a. Historical trends in mercury sedimentation and mixing in the Strait of Georgia, Canada. Environmental Science and Technology 39, 4361-4368.

Johannessen, S.C., O'Brien, M.C., Denman, K.L., Macdonald, R.W., 2005b. Seasonal and spatial variations in the source and transport of sinking particles in the Strait of Georgia, British Columbia, Canada. Marine Geology 216, 59-77.

Johannessen, S.C., Macdonald, R.W., Wright, C.A., Burd, B.J., Shaw, D.P., van Roodselaar, A., 2008. Joined by geochemistry, divided by history: PCBs and PBDEs in Strait of Georgia sediments, Marine Environmental Research, in press.

Johnson, N.A., Campbell, J.W., Moore, T.S., Rex, M.A., Etter, R.J., McClain, C.R., Dowell, M.D., 2007. The relationship between the standing stock of deep-sea macrobenthos and surface production in the western North Atlantic. Deep-Sea Research I 54, 1350-1360.

Jones, A.A., Ellis, D.V., 1975. Benthic community composition in the Crofton mill receiving area, 1974 and Recommendations on a routine monitoring program for benthic assessment, Dobrocky SeaTech Report to British Columbia Forest Products, 58 pp. 
732 Jumars, P.A., Banse, K., 1989. Benthos and its interaction with bottom boundary layer

733 processes, in: Landry, M.R., Hickey, B.M., (Eds.), Coastal Oceanography of Washington

734 and Oregon, Elsevier, Amsterdam, pp. 349-365.

735 Levin, L.A., Gage, J.D., 1998. Relationships between oxygen, organic matter and the diversity of 736 bathyal macrofauna. Deep-Sea Research Part II: Topical Studies in Oceanography 45, $737 \quad 129-163$.

738 Levings, C.D., Foreman, R.E., Tunnicliffe, V.J., 1983. Review of the benthos of the Strait of 739 Georgia and contiguous fjords. Canadian Journal of Fisheries and Aquatic Sciences 40, $740 \quad 1120-1141$.

741 Llansó, R.J., Aasen, S., Welch, K., 1998. Marine Sediment Monitoring Program: II. Distribution and structure of benthic communities in Puget Sound 1989-1993, Publication No. 98-328, Washington State Department of Ecology: Environmental investigations and laboratory services program, Olympia, Washington. $114 \mathrm{pp} .+$ appendices.

MacDonald, B.A., Ward, J.E., 1994. Variation in food quality and particle selectivity in the sea scallop Placopecten magellanicus (Mollusca: Bivalvia). Marine Ecology Progress Series $108,251-264$.

Macdonald, R.W., Cretney, W.J., Crewe, N., Paton, D., 1992. A history of octachlordibenzo-pdioxin, 2,3,7,8-tetrachlorodibenzofuran and 3,3', 4-4'-tetrachlorobiphenyl contamination in Howe Sound, British Columbia. Environmental Science \& Technology 26, 1544-1550.

751 Macdonald, R.W., Macdonald, D.M., O'Brien, M.C., Gobeil, C., 1991. Accumulation of heavy 752 metals $(\mathrm{Pb}, \mathrm{Zn}, \mathrm{Cu}, \mathrm{Cd})$, carbon and nitrogen in sediments from the Strait of Georgia, B.C., Canada. Marine Chemistry 34, 109-135. 
754 Macdonald, R.W., Johannessen, S.C., Gobeil, C., Wright, C., Burd, B.J., van Roodselaar, A., 2008. Sediment redox tracers in Strait of Georgia sediments - can they inform us of the loadings of organic carbon from municipal wastewater? Marine Environmental Research, in press .

Masson, D., 2002. Deep water renewal in the Strait of Georgia. Estuarine and Costal Shelf Science 54, 115-126.

Masson, D., Cummings, P.F., 2004. Observations and modeling of seasonal variability in the

Masson, D., Pena, M.A., (in prep.). Chlorophyll distribution in a temperate estuary: the Strait of Georgia and Juan de Fuca Strait. Estuarine, Coastal and Shelf Science.

764 McPherson, C.A., Bailey, H.C., Chapman, M.K., Lee, M.K., Burd, B.J., Fanning, M.L., Paine, M.D., Hamilton, M.C., Chen, F., 2003. Iona Deep-sea Outfall, 2002 Environmental Monitoring Program: Sediment Effects Survey, Prepared for the Greater Vancouver Regional District by EVS Consultants Ltd., Burnaby, B.C., 223 pp. + appendices.

771 McPherson, C.A., Chapman, M.K., Lee, M.K., Burd, B.J., Fanning, M.L., Hamilton, M.C., Chen, F., 2004a. Iona Deep-sea Outfall, 2003 Environmental Monitoring Program: Ambient Monitoring Program - Data Report, Prepared for the Greater Vancouver Regional District by EVS Consultants Ltd, Burnaby, BC, 28 pp.+ appendices. 
McPherson, C.A., Chapman, M.K., Lee, M.K., Fanning, M.L., Olson, J., Chen, F., 2004b. Lions Gate Outfall, 2003 Sediment Effects Survey, Prepared for the Greater Vancouver Regional District by EVS Consultants Ltd., Burnaby, BC, 99 pp.+ appendices. McPherson, C.A., Chapman, M.K., McKinnon, S., Burd, B.J., Fanning, M.L., Olson, J., Hamilton, M.C., Chen, F., 2005a. Iona Deep-sea Outfall, 2004 Environmental Monitoring Program: Sediment Effects Survey, Prepared for the Greater Vancouver Regional District by EVS Consultants Ltd., Burnaby, BC, 222 pp.+ appendices.

McPherson, C.A., Chapman, M.K., McKinnon, S., Burd, B.J., Fanning, M.L., Olson, J., Hamilton, M.C., Chen, F., 2006a. Iona Deep-sea Outfall, 2005 Environmental Monitoring Program: Sediment Effects Survey, Prepared for the Greater Vancouver Regional District by EVS Consultants Ltd., Burnaby, BC, 262 pp.+ appendices.

McPherson, C.A., Chapman, M.K., McKinnon, S., Burd, B.J., Fanning, M.L., Olson, J., Hamilton, M.C., Chen, F., 2007a. Iona Deep-sea Outfall, 2006 Environmental Monitoring Program: Sediment Effects Survey, Prepared for the Greater Vancouver Regional District by EVS Consultants Ltd., Burnaby, BC, 240 pp.+ appendices.

McPherson, C.A., Chapman, M.K., McKinnon, S.J., Fanning, M.L., Burd, B.J., Olson, J., Chen, F., Brooks, G., 2005b. Lions Gate Outfall, 2004 Sediment Effects Survey, Prepared for the Greater Vancouver Regional District by EVS Consultants Ltd, Burnaby, BC, 212 pp.+ appendices.

McPherson, C.A., Chapman, M.K., McKinnon, S., Fanning, M.L., Burd, B.J., Olson, J., Chen, F., Brooks, G., 2006b. Lions Gate Outfall, 2005 Sediment Effects Survey, Prepared for the Greater Vancouver Regional District by EVS Consultants Ltd., Burnaby, BC, 212 pp. + appendices. 
McPherson, C.A., Chapman, M.K., McKinnon, S.J., Fanning, M.L., Burd, B.J., Olson, J., Chen, F., Brooks, G., 2007b. Lions Gate Outfall, 2006 Sediment Effects Survey, Prepared for the Greater Vancouver Regional District by EVS Consultants Ltd., Burnaby, BC, 238 pp. + appendices.

Newell, R.I.E., Jordan, S.J., 1983. Preferential ingestion of organic material by the American oyster Crassostrea virginica. Marine Ecology Progress Series 13, 47-53.

Ostrovsky, I., 1987. Seabed responses to wood waste in Northumberland Channel. M.Sc., University of Victoria, Victoria, B.C.

Paine, Ledge and Associates, 2004. Trend Analysis of Macaulay Point Invertebrate Community Data 1994-2002, Prepared for the Capital Regional District, Environmental Services Department, Victoria, BC, Canada.

Pearson, T.H., 1980. Marine pollution effects of pulp and paper industry wastes. Helgolander Meeresunters 33, 340-365.

Pearson, T.H., Rosenberg, R., 1978. Macrobenthic succession in relation to organic enrichment and pollution of the marine environment. Oceanography and Marine Biology Annual Review 16, 229-311.

Pharo, C.H., Barnes, W.C., 1976. Distribution of surficial sediments of the central and southern Strait of Georgia, British Columbia. Canadian Journal of Earth Sciences 13, 684-696.

Picard, K., Hill, P.R., Johannessen, S.C., 2006. Sedimentation rates and surficial geology in the Canadian Forces Maritimes Experimental and Test Range exercise area Whiskey Golf, Strait of Georgia, British Columbia, in: Current Research no. 2006-A5, Geological Survey of Canada, Pacific Geoscience Centre, Sidney, BC, 9 pp. 
820 Robbins, J.A., 1978. Geochemical and geophysical applications of radioactive lead, in: Nriagu,

821 J.O., (Ed.), The Biogeochemistry of Lead in the Environment. North-Holland Biomedical

822 Press/Elsevier, New York, pp. 285-393.

823 Rowe, G., Sibuet, M., Deming, J., Khripoundoff, A., Tietjen, J., Macko, S., Theroux, R. 1991.

824 'Total' sediment biomass and preliminary estimates of organic carbon residence time in 825 deep-sea benthos. Marine Ecology Progress Series, 79, 99-114.

826 Schlitzer, R., 2006. Ocean Data View, http://odv.awi.de,

827 Seacology (Seacology Pacific Marine Life Surveys Inc)., Tera Environmental Consutants (Alta.)

828 Ltd., 2001. Biological Survey and Assessment of Benthic Habitats for a Proposed Manley

829 Creek Pipeline Landfall at Boatswain Bank, British Columbia-July 2000, Prepared for

830 Georgia Strait Crossing Pipeline Ltd., 47 pp. + appendices.

831 Shang, D.Y., Macdonald, R.W., Ikonomou, M.G., 1999. Persistence of nonylphenol and

832 ethyoxylate surfactants and their principle primary degradation products in sediments

833 from near a municipal outfall in the Strait of Georgia, British Columbia, Canada.

834 Environmental Science \& Technology 33, 1366-1372.

835 Shirayama, Y., 1984. The abundance of deep-sea meiobenthos in the western Pacific in relation 836 to environmental factors. Oceanogocia Acta 7, 113-121.

837 Striplin Environmental Associations, Roy F. Weston, Inc., (1999). Puget Sound Reference Value Project. Task 3: Development of Benthic Effects Sediment Quality Standards. U.S. Environmental Protection Agency, Region 10, Lacey, Washington, 84 pp. + appendices.

Striplin, P., 1996) Development of reference value ranges for benthic infauna assessment endpoints in Puget Sound, Washington State Dept. Ecology Sediment Management Unit, 44 pp. + appendices. 
843 Stucchi, D., 2006. Long term trends in deep water properties of BC inlets. Fisheries and Oceans

$844 \quad$ Canada. www.pac.dfo-mpo.gc.ca/SCI/osap/projects/bcinlets/default_e.htm;

845 Suess, E., 1980. Particulate organic carbon flux in the oceans - surface productivity and oxygen

$846 \quad$ utilization. Nature 288: 260-263.

847 Taghon, G.L., 1982. Optimal foraging by deposit-feeding invertebrates: roles of particle size and $848 \quad$ organic coating. Oecologia 52, 295-304.

849 Thorson, G., 1957. Bottom communities (sublittoral or shallow shelf), in: Hedgepeth, J.W. (Ed.),

850 Treatise on Marine Ecology and Paleoecology, Geological Society of America Memoirs, $851 \quad$ Volume 67, pp. 461-534.

852 Tunnicliffe, V., 1981. High species diversity and abundance of the epibenthic community in an 853 oxygen-deficient basin. Nature 294, 354-356.

854 Vanaverbeke, J., Soetaert, K., Heip, C., Vanreusel, A., 1997. The metazoan meiobenthos along the continental slope of the Goban Spur (NE Atlantic). Journal of Sea Research 38, 93 107.

857 Vinogradov, M.E., Tseitlin, V.B., 1983) Deep-sea pelagic domain (aspects of bioenergetic), in:

858 Rowe, G., (Ed.), The Sea. Deep-Sea Biology, Vol 8. Wiley, New York, pp. 123-165.

859 Webster, J.R., Benfield, E.F., 1986. Vascular plant breakdown in freshwater ecosystem. Annual

$860 \quad$ Reviews in Ecological Systems 17, 567-594.

861 Whitney, F.A., Wong, C.S., 1984. Carbon cycling in the shallow waters of Saanich Inlet.

862 Proceedings of a Multidisciplinary Symposium on Saanich Inlet, 2nd February, 1983.

863 Canadian Technical Report of Hydrography and Ocean Sciences 38, 45-49.

864 Wlodarska-Kowalczuk, M., 2007. Molluscs in Kongsfjorden (Spitsbergen, Svalbard): a species

865 list and patterns of distribution and diversity. Polar Research 26, 48-63. 
866

867

868

869

870

871

872

873

874

875

876

877

878

879

880

881

882

883

884

885

886

887

888

Wlodarska-Kowalczuk, M., Kendall, M.A., Weslawski, J.M., Klages, M., Soltwedel, T., 2004. Depth gradients of benthic standing stock and diversity on the continental margin at a high-latitude ice-free site (off Spitsbergen, 79N). Deep-Sea Research Part I, Oceanographic Research Papers 51, 1903-1914.

Wlodarska-Kowalczuk, M., Pearson, T.H., 2004. Soft-bottom macrobenthic faunal associatons and factors affecting species distributions in an Arctic glacial fjord (Kongsfjord, Spitsbergen). Polar Biology 27, 155-167.

Wlodarska-Kowalczuk, M., Pearson, T.H., Kendall, M.A., 2005. Benthic response to chronic natural physical disturbance by glacial sedimentation in an Arctic fjord. Marine Ecology Progress Series 303, 31-41.

Wlodarska-Kowalczuk, M., Sicinski, J., Gromisz, S., Kendall, M.A., Dahle, S., 2007. Similar soft-bottom polychaete diversity in Arctic and Antarctic marine inlets. Marine Biology $151,607-616$.

Wright, C., Taekema, B., Burd, B., Dalby Jr., J., McGreer, E.R., 2007a. Salmon Aquaculture Environmenal Monitoring Data Report. Results of Sampling Program for Year 2001, A Report Prepared for the Ministry of the Environment, Province of British Columbia, Nanaimo, B.C.

Wright, C., Taekema, B., Burd, B., McGreer, E., 2007b. Salmon Aquaculture Environmental Monitoring Data Report. Results of Sampling Program for Year 2000, A Report Prepared for the Ministry of the Environment, Province of British Columbia, Nanaimo, B.C.

Wright, C., Taekema, B., Burd, B., McGreer, E.R., 2007c. Salmon Aquaculture Environmental Monitoring Data Report. Results of Sampling Program for Year 2002, A Report Prepared for the Ministry of the Environment, Province of British Columbia, Nanaimo, B.C. 
889

890

891

892

893

894

895

896

897

898

899

900

901

902

903

904

905

Wright, C., Taekema, B., Burd, B., McGreer, E.R., 2007d. Salmon Aquaculture Environmental Monitoring Data Report. Results of Sampling Program for Year 2003, A Report Prepared for the Ministry of the Environment, Province of British Columbia, Nanaimo, B.C.

Wright, C., Taekema, B., Burd, B., McGreer, E.R., 2007e. Salmon Aquaculture Environmental Monitoring Data Report. Results of Sampling Program for Year 2004, A Report Prepared for the Ministry of the Environment, Province of British Columbia, Nanaimo, B.C.

Wright, C.A., Johannessen, S.C., Macdonald, R.W., Burd, B.J., Hill, P.R., van Roodselaar, A., Bertold, S., 2008. The Strait of Georgia Ambient Monitoring Program, Phase I 20022007: Sediment and Benthos. Canadian Data Report of Fisheries and Aquatic Sciences, in press.

Yunker, M.B., Macdonald, R.W., 2003. Petroleum biomarker sources in suspended particulate matter and sediments from the Fraser River Basin and Strait of Georgia, Canada. Organic Geochemistry 34, 1525-1541.

Yunker, M.B., Macdonald, R.W., Goyette, D., Paton, D.W., Fowler, B.R., Sullivan, D., Boyd, J., 1999. Natural and anthropogenic inputs of hydrocarbons to the Strait of Georgia. Science of the Total Environment 225, 181-209.

Zar, J.H., 1984. Biostatistical analysis, Prentice-Hall, Inc., Englewood Cliffs, N.J. USA, 620 pp. 


\section{Figure Captions}

907

908 Figure 1. General locations of historical and AMP grab sample data, with overlying bottom

909 bathymetry based on multibeam data (courtesy of Natural Resources Canada) for the main basin

910 of the Strait of Georgia. Multibeam data are not available for the adjacent fjords. The locations of

911 the nine AMP grab sample locations are shown as white dots (which correspond with the AMP

912 core locations; see Fig. 2). Locations of pulp mills, outfalls and the Britannia Beach acid mine

913 drainage site are included. Note FR denotes Fraser River.

914

915 Figure 2. Locations of historical and nine AMP cores from the Strait of Georgia. Historical core

916 names from the original reports are listed in Table 2.

917

918 Figure 3. Total abundance, taxa number and abundance of dominant taxonomic groups for

919 historical and AMP grab samples versus sample depth. Mean background values +/-SE for each

920 biological factor are superimposed for arbitrarily selected depth ranges (points are shown on the

921 plot at the maximum depth for that range). Note that mean values do not include any data for

922 samples taken near anthropogenic discharges.

923

924 Figure 4. Total abundance, taxa number and abundance of dominant taxonomic groups for

925 historical and AMP grab samples versus sample percent silt/clay. Mean background values +/-

926 SE for each biological factor are superimposed for arbitrarily selected depth ranges (points are

927 shown on the plot at the maximum depth for that range). Note that mean values do not include

928 any data for samples taken near anthropogenic discharges. 
930 Figure 5. Total abundance, taxa number and abundance of dominant taxonomic groups for

931 historical and AMP grab samples versus \%TOC. Mean background values +/-SE for each

932 biological factor are superimposed for arbitrarily selected depth ranges (points are shown on the

933 plot at the maximum depth for that range). Note that mean values do not include any data for

934 samples taken near anthropogenic discharges.

935

936 Figure 6. Total abundance, taxa number and abundance of dominant taxonomic groups for

937 historical and AMP grab samples versus sample \%TN. Mean background values +/-SE for each

938 biological factor are superimposed for arbitrarily selected depth ranges (points are shown on the

939 plot at the maximum depth for that range). Note that mean values do not include any data for

940 samples taken near anthropogenic discharges.

942 Figure 7. a. Geographic distribution of sediment fluxes and, b; sediment organic carbon flux

943 rates from AMP and historical core data (as per Table 2). Locations of cores are shown as black

944 dots on the figure and correspond to core locations shown in Figure 2. Locations of pulp and

945 paper mills, outfalls and the Britannia Beach acid mine drainage are included for reference.

947 Figure 8. a; Geographic distribution of total abundance per grab, and b; bivalve abundance per

948 grab for background locations in the Strait of Georgia, including several sample locations off

949 southern Victoria in Juan de Fuca Strait. Locations of pulp and paper mills, outfalls and the

950 Britannia Beach acid mine drainage are included for reference. 
952 Figure 9. Geographic distribution of taxa number per grab for background locations in the Strait 953 of Georgia, including Parry Bay and Macaulay point area in Juan de Fuca Strait. Locations of

954 pulp and paper mills, outfalls and the Britannia Beach acid mine drainage are included for 955 reference.

956

957 Figure 10. a; Distribution of carbon stable isotope composition $\left(\delta^{13} \mathrm{C}\right)$ relative to $\%$ TOC, and, b; 958 distribution of nitrogen stable isotope composition ( $\mathrm{d} 15 \mathrm{~N})$ relative to $\% \mathrm{TN}$ for all depth layers 959 in AMP cores (see Fig. 2 for locations of cores). Outfall samples show a divergence of old 960 sediments deep in the core (pre-outfall) and newer sediments (post-outfall) based on $\delta^{15} \mathrm{~N}$ 961 values, c; the progression from terrestrial (near the Fraser River) to marine (most northerly part 962 of the Strait) organic deposition sources is shown in increasing $\delta^{15} \mathrm{~N} / \delta^{13} \mathrm{C}$ ratios (see arrow in 963 Fig. 10c). Cores 1 and 10 were from the most northern locations in the Strait, whereas cores 2-7 964 and 9 were collected in the southern basin (south of Texada Island - Fig. 1).

965

966 Figure 11. Best fit exponential regression line for log taxa number per grab versus

967 organic/inorganic flux from AMP grab and core samples $\left(r^{2}=0.83, p<0.001\right)$. Superimposed are

968 data points for taxa versus \% TN from the historical grab data for background locations and 969 anthropogenic sites (exponential regression fits for these data; $\mathrm{r}^{2}=0.66, \mathrm{p}<0.001$ ).

970

971 Figure 12. Best fit regression line $\left(\mathrm{r}^{2}=0.84, \mathrm{p}<0.01\right)$ for relationship of mean infaunal biomass

972 versus buried organic carbon flux to sediments for 9 AMP locations (see Fig. 2 for AMP

973 locations).

974 


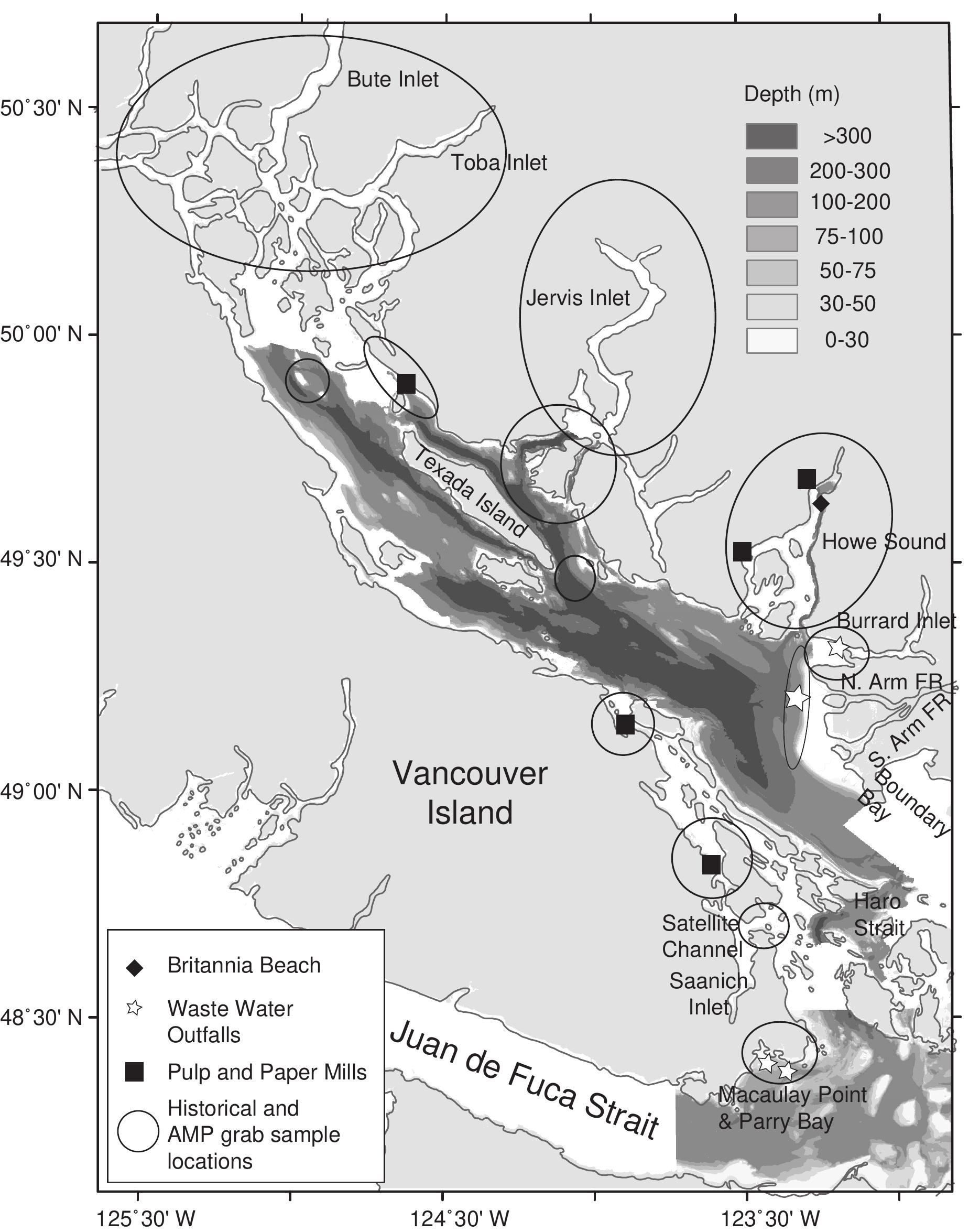




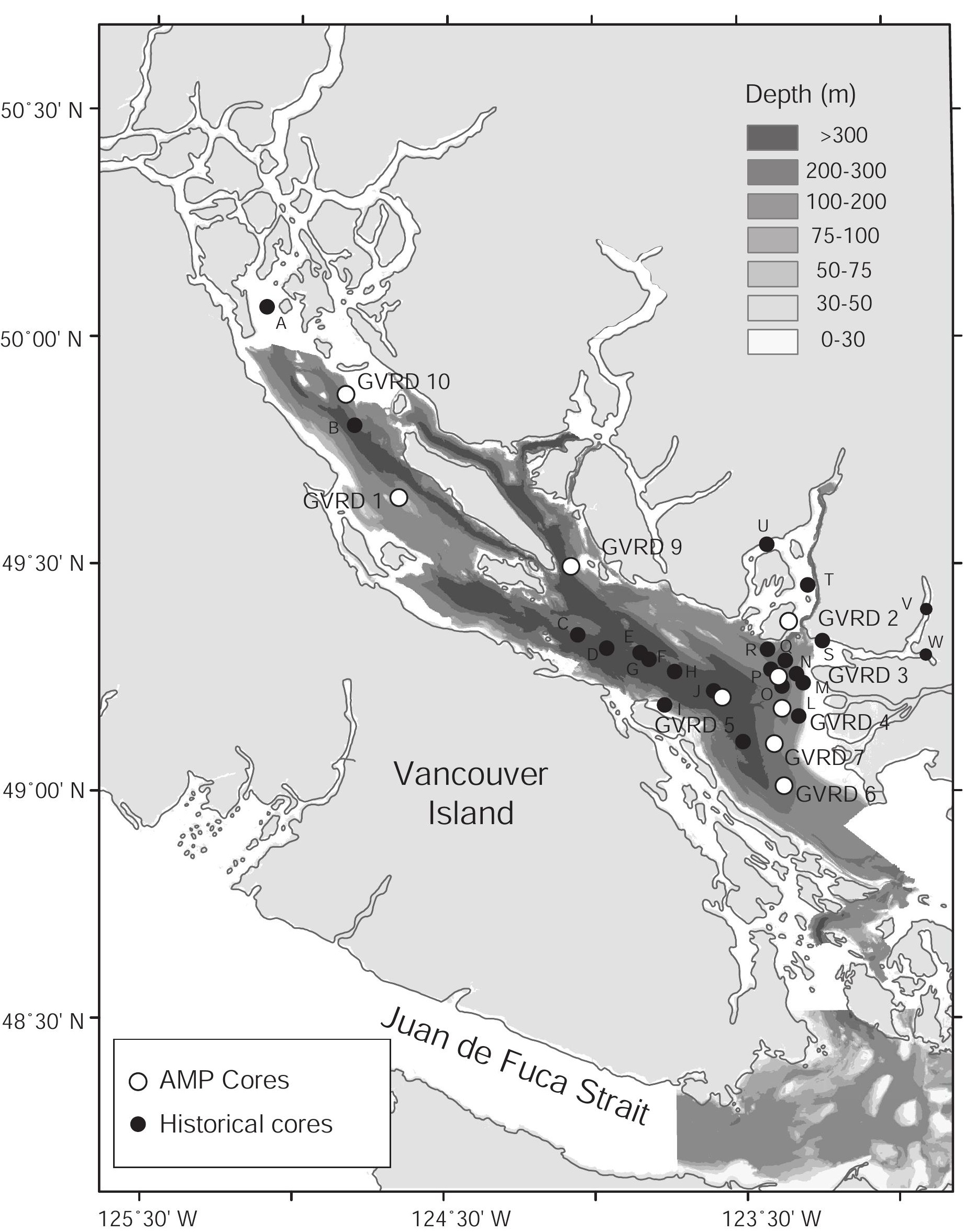




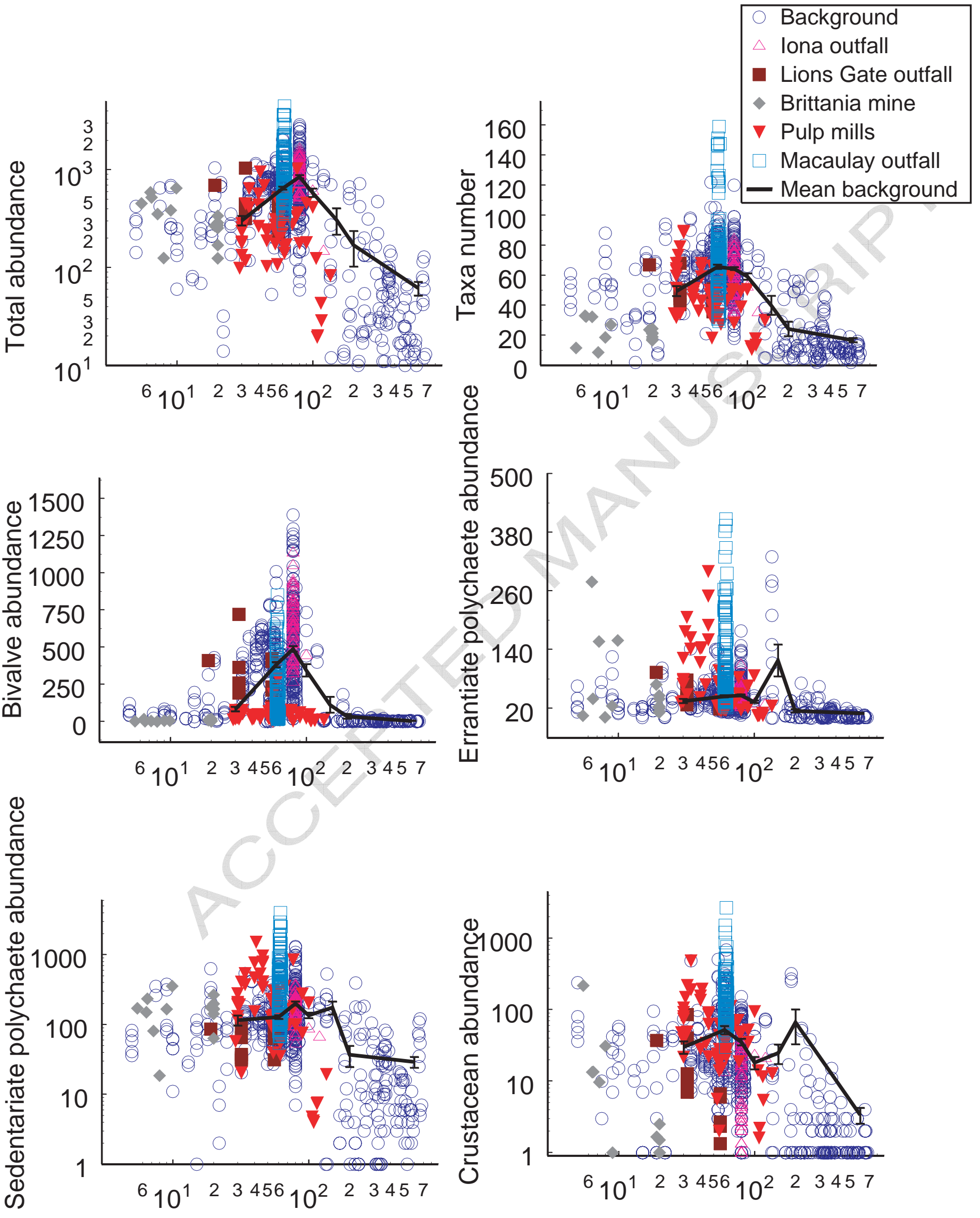

Depth (m) 

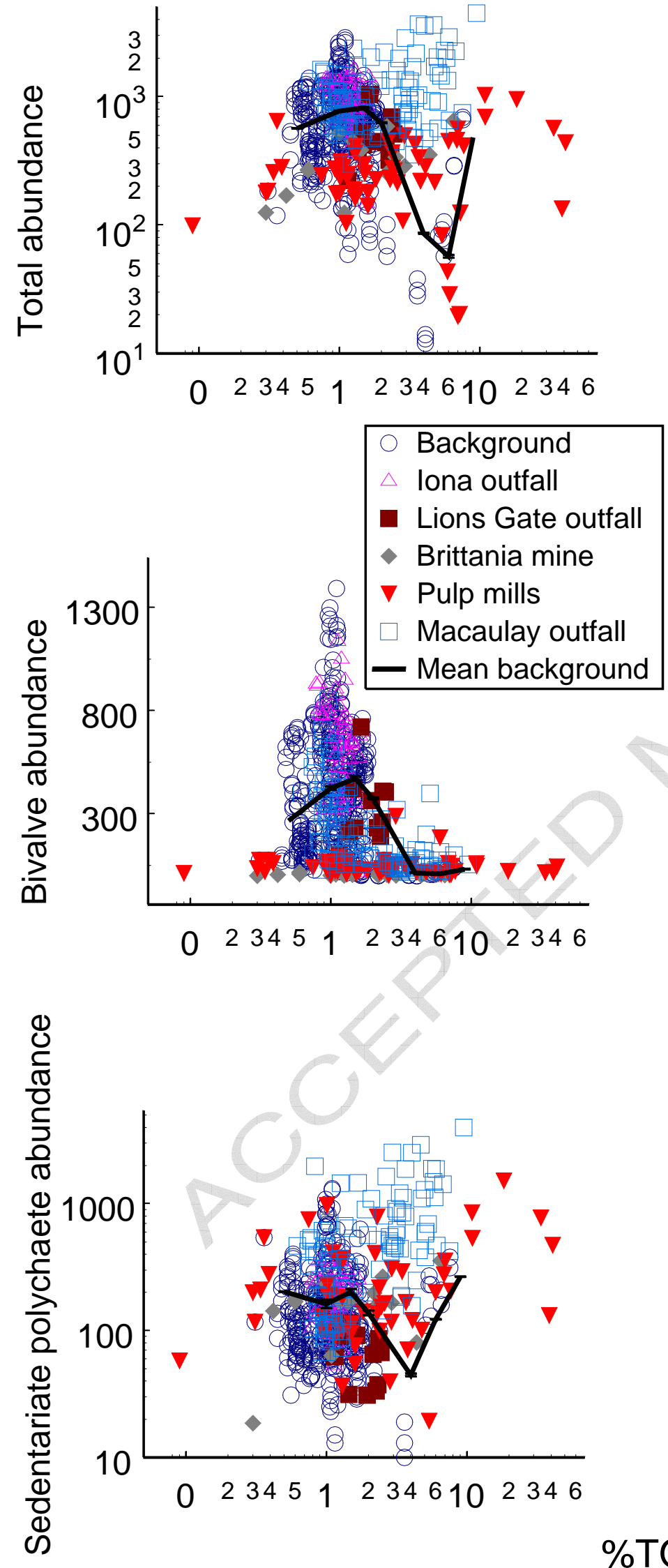
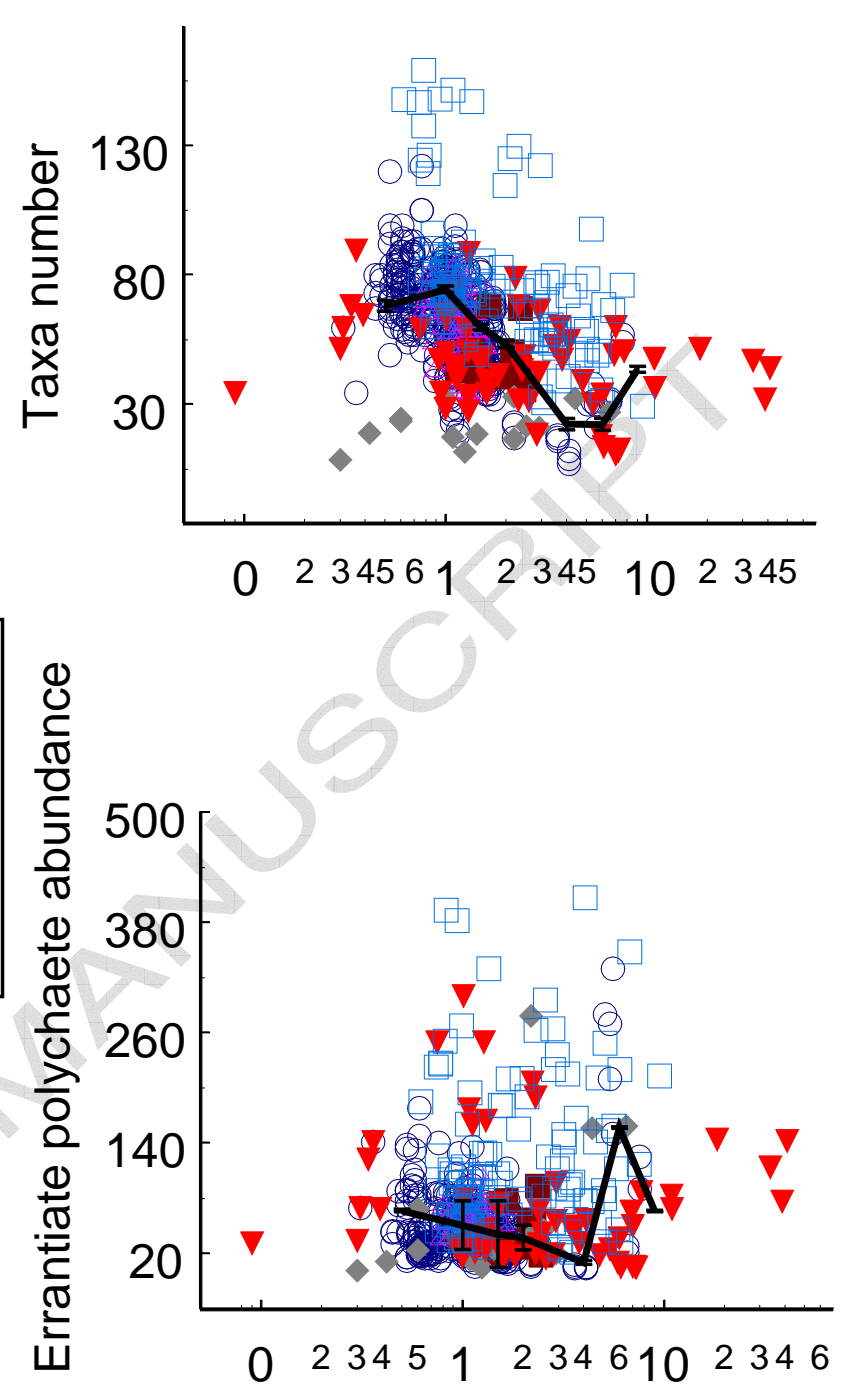

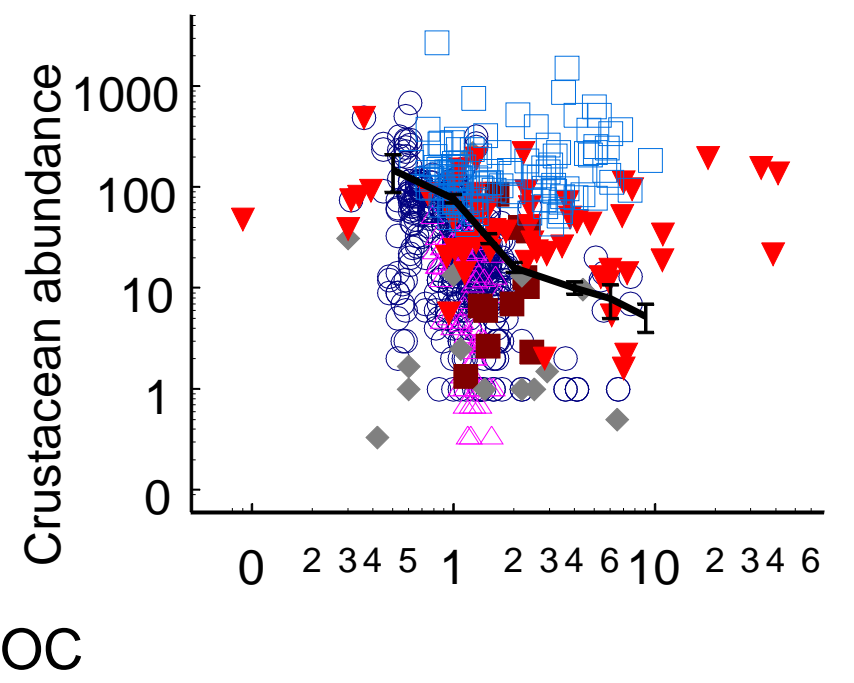

\%TOC 

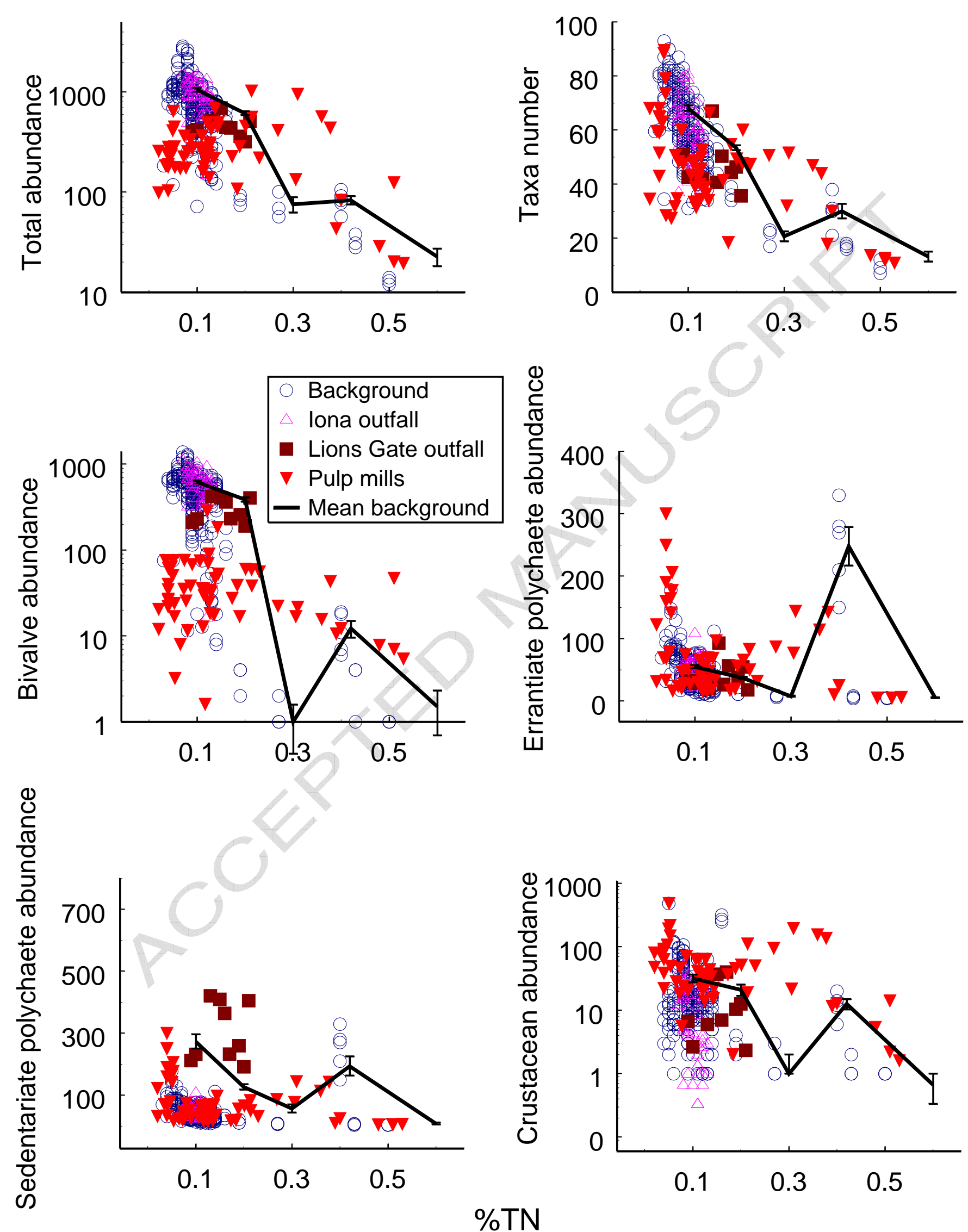
a

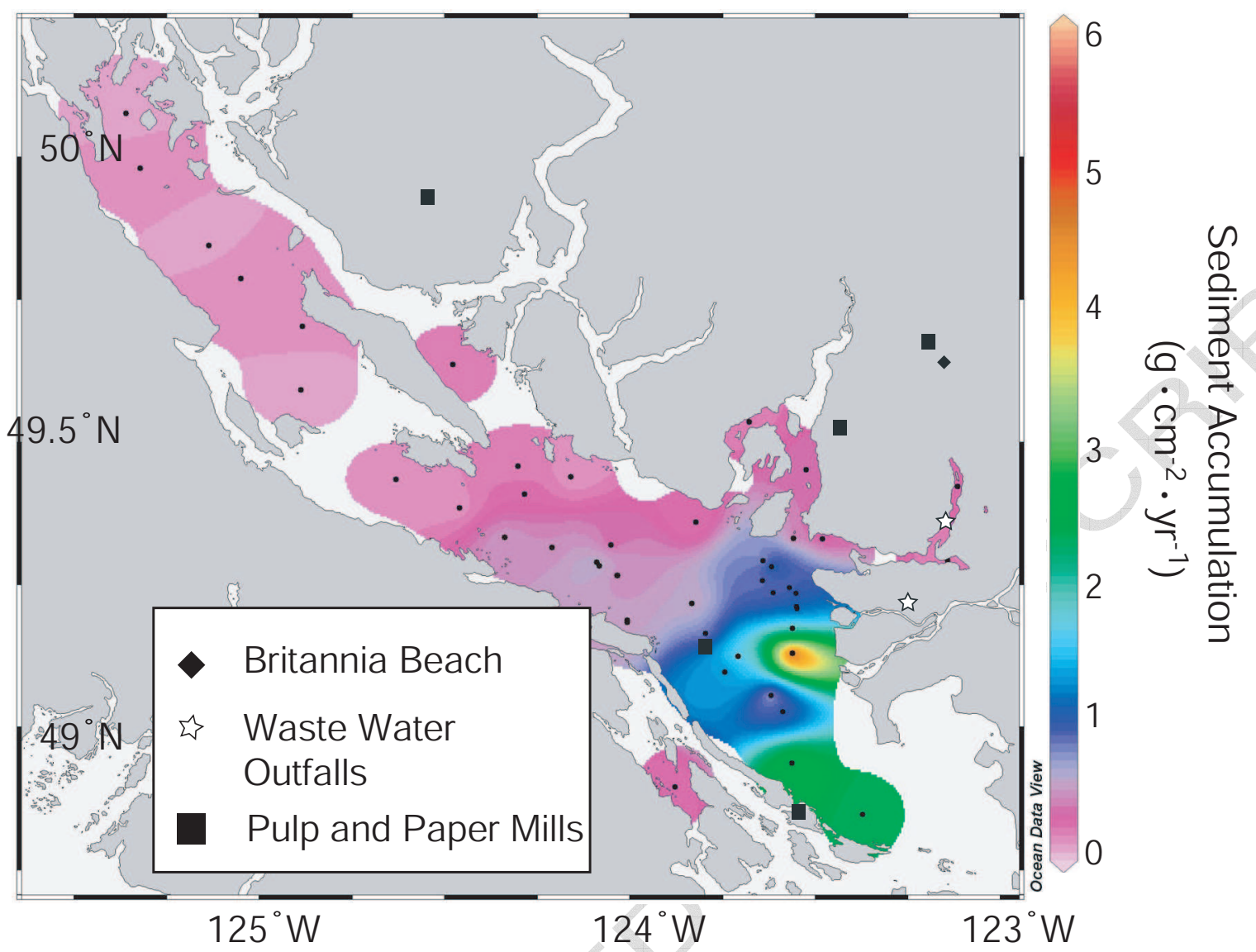

b

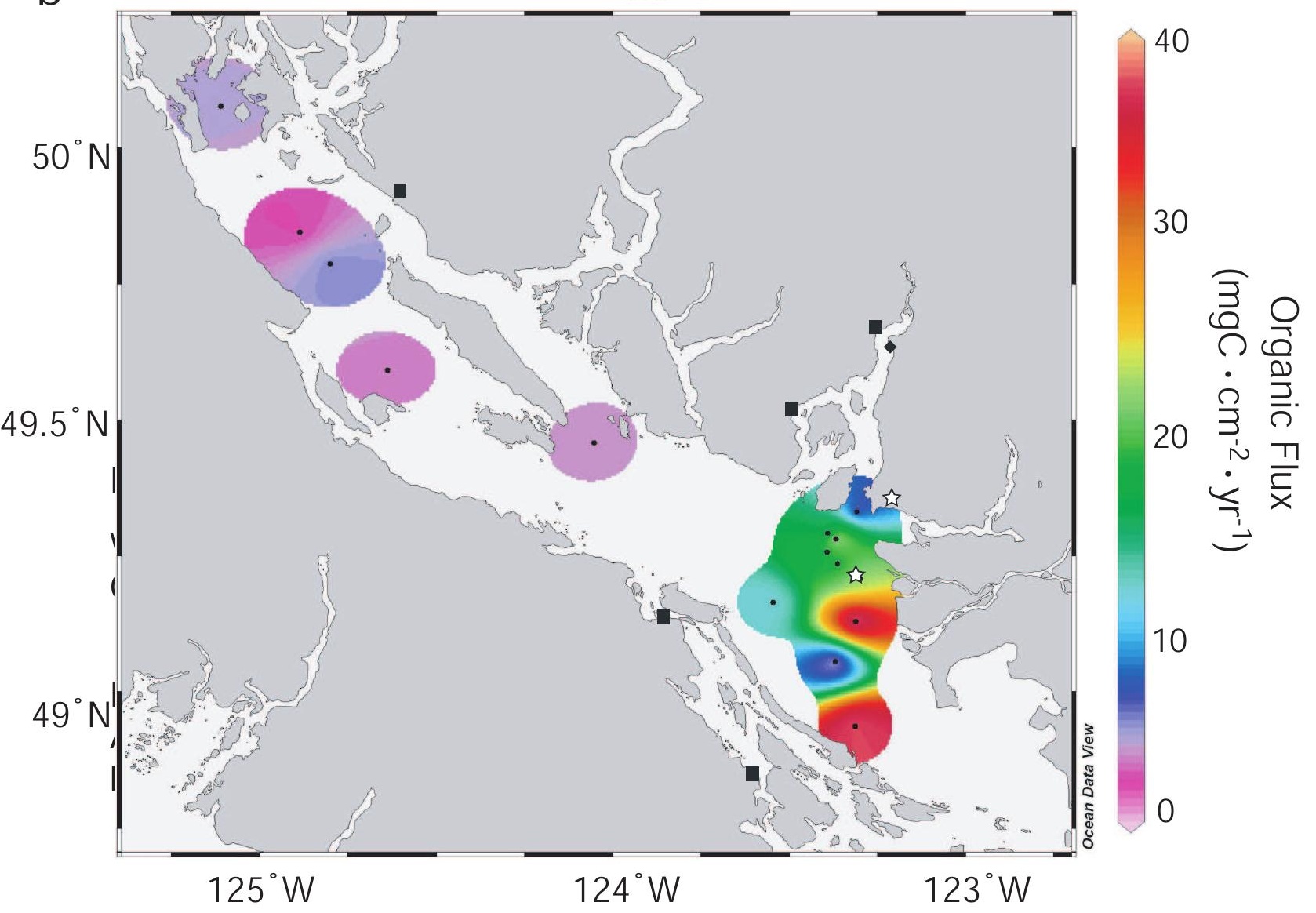


a
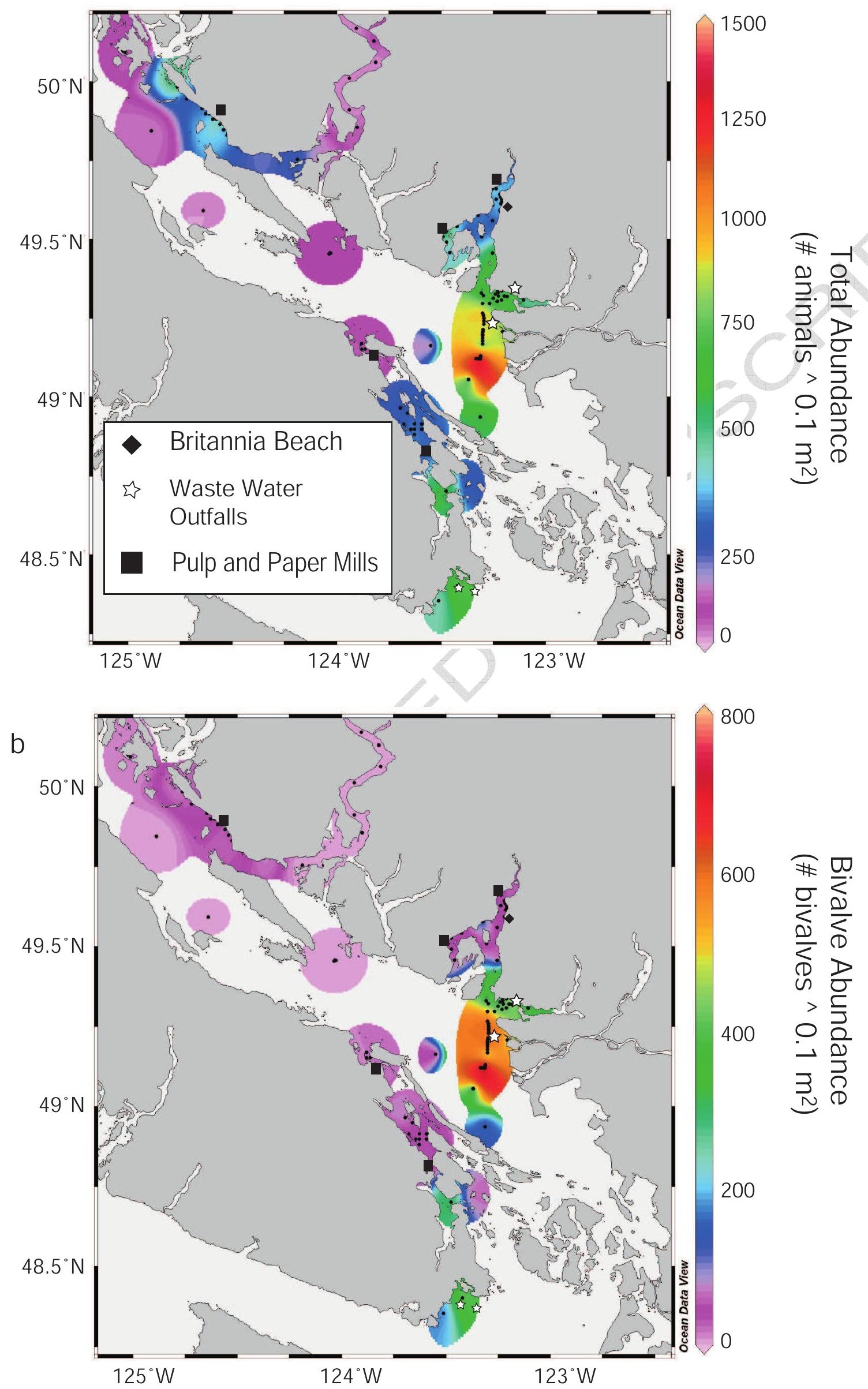


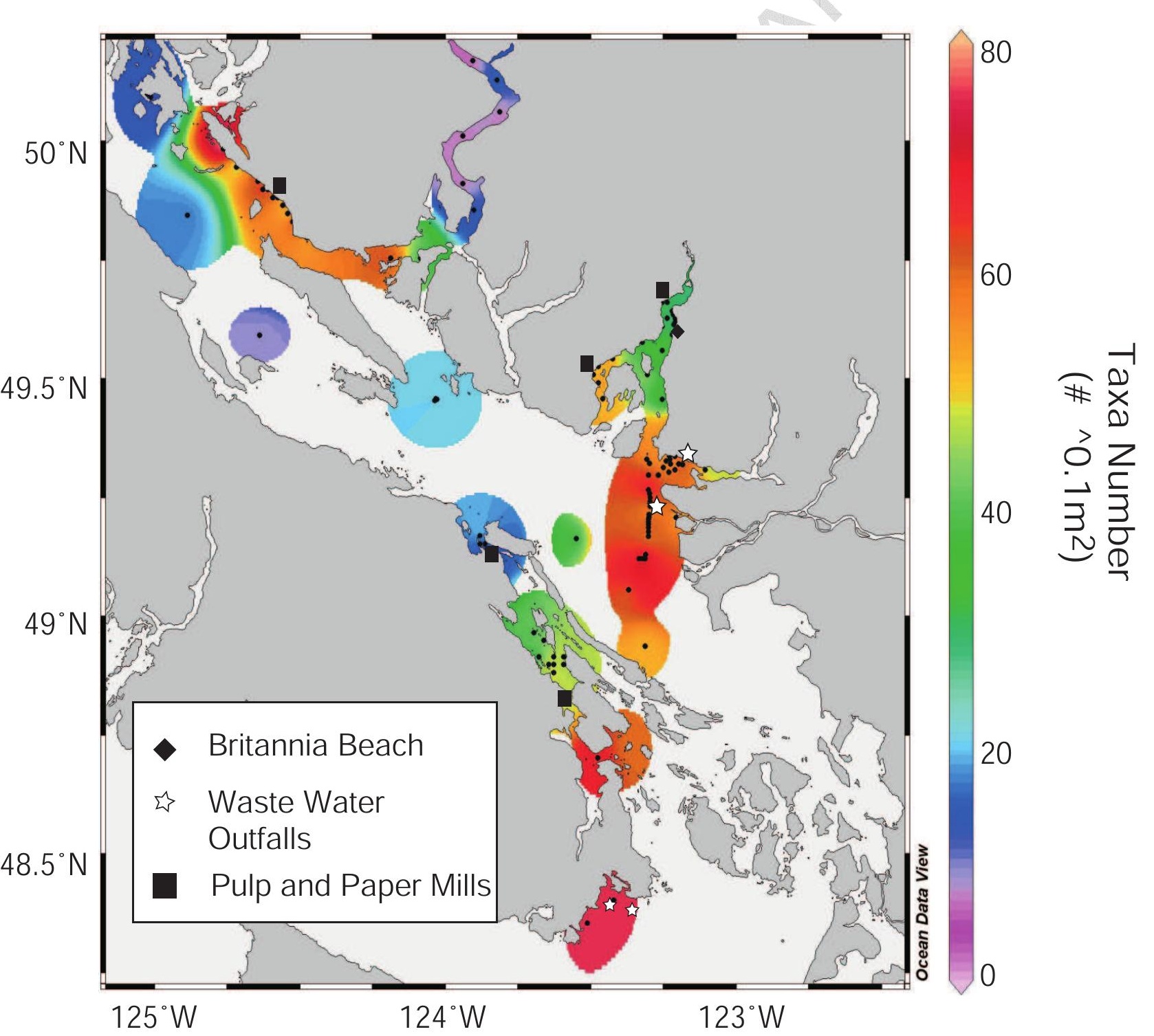


Ratio: organic/inorganic flux to sediments

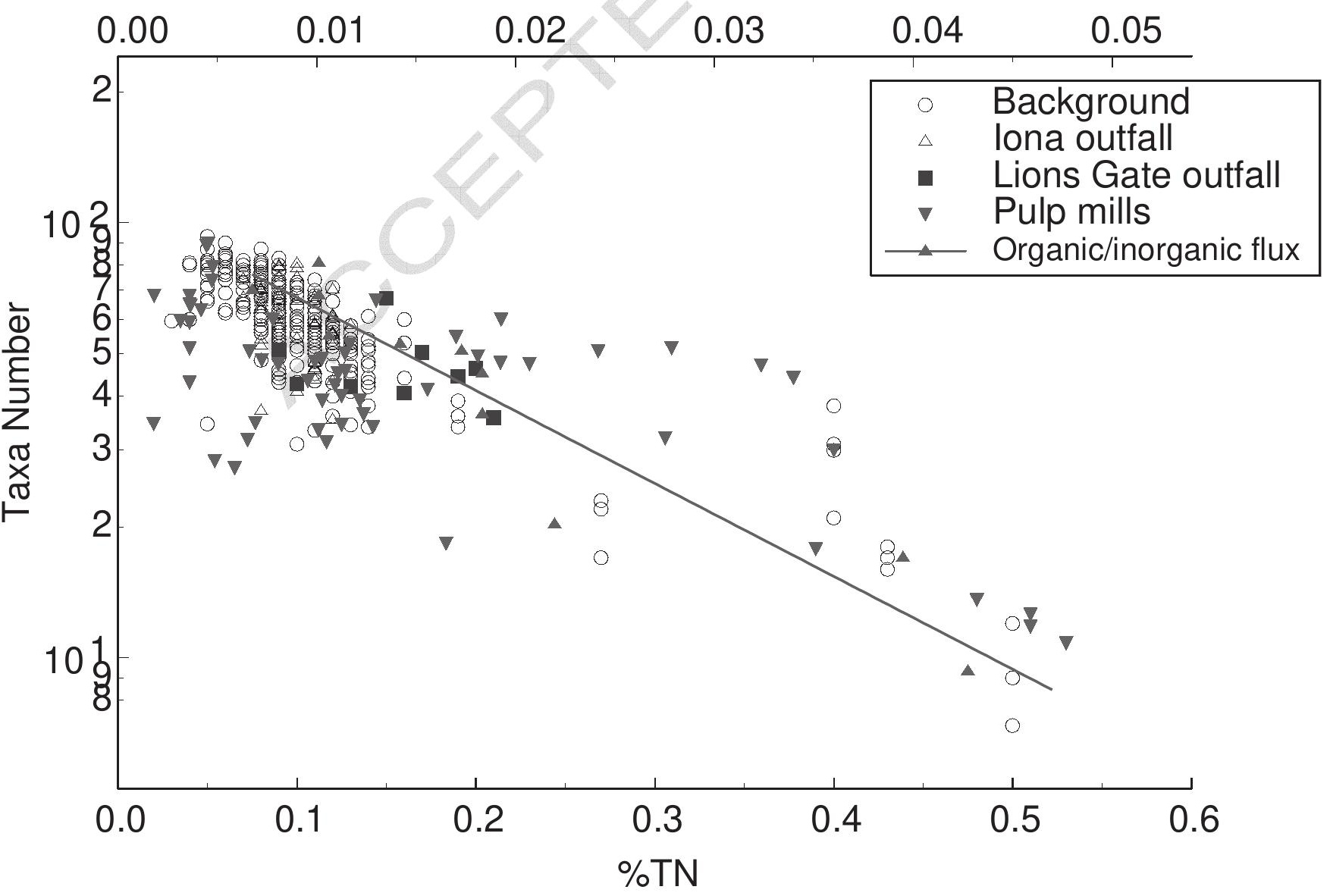


Table 1. Area, Depth, Year, Purpose of study and data source (reference) for historical and AMP grab sample data collected from 1988 to 2007.

\begin{tabular}{|c|c|c|c|c|}
\hline Region & Depth & Year & Purpose of study & References \\
\hline & (m) & & & \\
\hline $\begin{array}{l}\text { West coast } \\
\text { Vancouver Island, } \\
\text { Alberni Inlet }\end{array}$ & $25-45$ & 2000 & Ambient for pulp mill & $\begin{array}{l}\text { Pulp and Paper Environmental Monitoring } \\
\text { Program: } \\
\text { ec.gc.ca/eem/english/PulpPaper/default.cfm }\end{array}$ \\
\hline $\begin{array}{l}\text { Southeast Strait of } \\
\text { Georgia }\end{array}$ & $60-70$ & 1994-2004 & Ambient for Outfall & CRD 2003, 2004, 2005, Paine et al. 2004 \\
\hline Howe Sound & $5-20$ & 2000 & $\begin{array}{l}\text { Brittania Beach, acid mine } \\
\text { drainage }\end{array}$ & G3, 2003 \\
\hline $\begin{array}{l}\text { Ecological Reserve } \\
\text { 67, Southern Gulf } \\
\text { Islands }\end{array}$ & $60-70$ & 1999 & Background for pipeline & Burd et al., 2000 \\
\hline Mainland fjords & 221-634 & $1988-1990$ & Ambient for deep fjords & Burd and Brinkhurst, 1992 \\
\hline $\begin{array}{l}\text { Gorge Harbour, } \\
\text { Cortes Island; Village } \\
\text { Bay, Quadra Island }\end{array}$ & $13-37 \mathrm{~m}$ & 2005 & $\begin{array}{l}\text { Reference related to oyster farm } \\
\text { biodeposition }\end{array}$ & Barnes, 2007 \\
\hline $\begin{array}{l}\text { Southeast Strait of } \\
\text { Georgia }\end{array}$ & 80 & $2000-2005$ & Ambient for Iona outfall & $\begin{array}{l}\text { Bailey et al., 2003, McPherson et al., } \\
\text { 2003, 2004a, 2005a, 2006a, 2007a }\end{array}$ \\
\hline Outer Burrard Inlet & $55-75$ & 2002-2005 & Ambient for Lions Gate outfall & $\begin{array}{l}\text { McPherson et al,. 2004b, 2005b, 2006b, } \\
\text { 2007b }\end{array}$ \\
\hline $\begin{array}{l}\text { Northern Strait of } \\
\text { Georgia: Johnstone } \\
\text { St }\end{array}$ & $30-100$ & $2000-2002$ & BCMOE Fish farm monitoring & Wright et al., 2007 a-e, \\
\hline $\begin{array}{l}\text { Southeast Vancouver } \\
\text { Island }\end{array}$ & $1-25$ & 2000 & Background for pipeline landing & $\begin{array}{l}\text { Seacology, 2001; Glaholt et al., 2002; Burd } \\
\text { and Glaholt, } 2000\end{array}$ \\
\hline Strait of Georgia & $80-340$ & $\begin{array}{l}2003,2004 \\
2006,2007\end{array}$ & $\begin{array}{l}\text { Ambient monitoring for Strait } \\
\text { of Georgia }\end{array}$ & $\begin{array}{l}\text { Wright et al,. 2008, McPherson et al., } \\
2004 \mathrm{c}\end{array}$ \\
\hline
\end{tabular}


Table 2. List of AMP cores (GVRD 1-7, 9,10) and historical cores, including original published names and coded labels used in Fig 2 , year of collection and source for AMP (GVRD 1-7,9,10) and historical cores. Core locations are shown in Fig. 2.

\begin{tabular}{|c|c|c|c|}
\hline Station & $\begin{array}{c}\text { Code } \\
\text { (Fig. 2) }\end{array}$ & $\begin{array}{c}\text { Year } \\
\text { Collected }\end{array}$ & Reference \\
\hline 17 & Q & 1993 & Yunker et al., 1999; Johannessen et al., 2005a, b \\
\hline 21 & $\mathrm{O}$ & 1993 & Yunker et al., 1999; Johannessen et al., 2005a, b \\
\hline 31 & $\mathrm{P}$ & 1993 & Yunker et al., 1999; Johannessen et al., 2005a, b \\
\hline A & $\mathrm{R}$ & 1993 & Yunker et al., 1999; Johannessen et al., 2005a, b \\
\hline BB1 & $\mathrm{J}$ & 1990 & Macdonald et al., 1992; Johannessen et al., 2005a, b \\
\hline BC-2 & G & & Johannessen et al., 2005a, b \\
\hline CM-3 & $\mathrm{K}$ & 1997 & Johannessen et al., $2005 a, b$ \\
\hline CM-4 & $\mathrm{F}$ & 1997 & Johannessen et al., 2005a, b \\
\hline FD-12 & $\mathrm{L}$ & 1996 & Shang et al., 1999; Johannessen et al., 2005a, b \\
\hline FD-22 & M & 1996 & Shang et al., 1999; Johannessen et al., 2005a, b \\
\hline FD-3 & $\mathrm{N}$ & 1996 & Shang et al., 1999; Johannessen et al., 2005a, b \\
\hline HS-1 & $\mathrm{T}$ & 1990 & Macdonald et al., 1992; Johannessen et al., 2005a, b \\
\hline IND-VI & V & 1994 & Boyd et al., 1997; Johannessen et al., 2005a, b \\
\hline PEI & S & 1994 & Boyd et al., 1997; Johannessen et al., 2005a, b \\
\hline $\mathrm{PM}-\mathrm{V}$ & $\mathrm{W}$ & 1994 & Boyd et al.,1997;Yunker et al., 1999; Johannessen et al., 2005a, b \\
\hline SC & A & 2001 & Johannessen et al., 2005a, b \\
\hline TC-1 & $\mathrm{U}$ & 1990 & Macdonald et al., 1992; Johannessen et al., 2005a, b \\
\hline $\mathrm{TI}$ & $\mathrm{B}$ & 2001 & Johannessen et al., 2005a, b \\
\hline Vec04A-10 & $\mathrm{D}$ & 2004 & Picard et al., 2006 \\
\hline Vec04A-11 & I & 2004 & Picard et al., 2006 \\
\hline Vec04a-15 & $\mathrm{C}$ & 2004 & Picard et al., 2006 \\
\hline Vec04A-16 & $\mathrm{E}$ & 2004 & Picard et al., 2006 \\
\hline Vec04A-17 & $\mathrm{H}$ & 2004 & Picard et al., 2006 \\
\hline GVRD-1 & GVRD-1 & 2003 & Wright et al., 2008 \\
\hline GVRD-2 & GVRD-2 & 2003 & Wright et al., 2008 \\
\hline GVRD-3 & GVRD-3 & 2002 & Wright et al., 2008 \\
\hline GVRD-4 & GVRD-4 & 2002 & Wright et al., 2008 \\
\hline GVRD-5 & GVRD-5 & 2002 & Wright et al., 2008 \\
\hline
\end{tabular}




\begin{tabular}{|r|r|r|l|}
\hline GVRD-6 & GVRD-6 & 2003 & Wright et al., 2008 \\
\hline GVRD-7 & GVRD-7 & 2003 & Wright et al., 2008 \\
\hline GVRD-9 & GVRD-9 & 2007 & Wright et al., 2008 \\
\hline GVRD-10 & GVRD-10 & 2007 & Wright et al., 2008 \\
\hline
\end{tabular}


Table 3. Summary data for AMP core and grab samples (Wright et al. 2008). Sample locations are shown in Fig. 2. Biotic values are means for three replicate grabs for each location. All mean abundance values are per grab $\left(0.1 \mathrm{~m}^{2}\right)$

\begin{tabular}{|c|c|c|c|c|c|c|c|c|c|}
\hline & GVRD-1 & GVRD-2 & GVRD-3 & GVRD-4 & GVRD-5 & GVRD-6 & GVRD-7 & GVRD-9 & GVRD-10 \\
\hline Sediment accumulation rate $\left(\mathrm{g}^{\wedge} \mathrm{cm}^{-2} \wedge \mathrm{a}\right)$ & 0.08 & 0.26 & 1.34 & $4.00^{+}$ & 0.64 & 2.70 & 0.32 & 0.16 & 0.059 \\
\hline Organic carbon flux (mg $\left.\mathrm{C}^{\wedge} \mathrm{cm}^{-2} \wedge \mathrm{yr}\right)$ & 3.18 & 4.68 & 22.78 & 40.00 & 11.50 & 37.80 & 3.31 & 3.44 & 1.90 \\
\hline Inorganic flux $\left(\mathrm{mg}^{\wedge} \mathrm{cm}^{-2} \wedge \mathrm{yr}\right)$ & 74.42 & 255.32 & 1317.22 & $3960.00+$ & 627.50 & 2662.20 & 311.69 & 156.56 & 48.19 \\
\hline Organic carbon/inorganic flux & 0.043 & 0.018 & 0.017 & 0.010 & 0.018 & 0.014 & 0.011 & 0.022 & 0.038 \\
\hline Buried organic carbon flux $\left(\mathrm{mg}^{\wedge} \mathrm{cm}^{-2} \wedge \mathrm{r}\right)$ & 2.48 & 1.60 & 10.72 & 36.00 & 9.59 & 29.16 & 3.09 & 2.4 & 1.5 \\
\hline Oxidized organic carbon flux ( $\left.\mathrm{mg} \mathrm{C} \mathrm{cm}^{-2} \cdot \mathrm{yr}\right)$ & 0.70 & 2.18 & 12.06 & 3.60 & 1.92 & 8.64 & 0.22 & 1.4 & 0.40 \\
\hline Organic carbon flux $/ \delta^{15} \mathrm{~N}$ & 0.48 & 1.00 & 10.00 & 11.20 & 1.93 & 6.57 & 0.59 & 0.49 & 0.27 \\
\hline Water depth of sample $(\mathrm{m})$ & 169 & 76 & 83 & 84 & 388 & 187 & 233 & 365 & 309 \\
\hline$\% \mathrm{TN}^{*}$ & 0.51 & 0.15 & 0.12 & 0.09 & 0.19 & 0.16 & 0.13 & 0.27 & 0.43 \\
\hline \%Carbonate* & 0.03 & 0.10 & 0.15 & 0.19 & 0.08 & 0.09 & 0.09 & 0.06 & 0.07 \\
\hline$\% \mathrm{TOC}^{*}$ & 4.07 & 1.54 & 1.15 & 0.91 & 1.65 & 1.32 & 1.01 & 2.19 & 3.60 \\
\hline$\%$ TOC/\%TN* & 8.01 & 10.41 & 9.53 & 10.31 & 8.55 & 8.26 & 8.08 & 8.11 & 8.37 \\
\hline Acid-volatile sulphides* $(\mu \mathrm{mol} / \mathrm{g})$ & 2.00 & 2.00 & 11.47 & 0.20 & 0.10 & 1.33 & 0.10 & $\mathrm{~N} / \mathrm{A}$ & $\mathrm{N} / \mathrm{A}$ \\
\hline$\delta^{15} N^{*}$ & 6.58 & 4.69 & 2.28 & 3.57 & 5.95 & 5.76 & 5.57 & 7.00 & 7.10 \\
\hline$\delta^{13} C^{*}$ & -21.24 & -23.85 & -24.43 & -24.83 & -22.54 & -21.62 & -22.71 & -21.34 & -20.30 \\
\hline Mean taxa per grab & 9.33 & 45.00 & 50.80 & 77.80 & 36.33 & 52.67 & 55.00 & 20.3 & 17.00 \\
\hline Mean total abundance & 13 & 231 & 788 & 2015 & 84 & 640 & 233 & 75.3 & 32.30 \\
\hline Mean biomass $\left(\mathrm{g} \cdot 0.1 \mathrm{~m}^{-2}\right)$ & 1.13 & 7.30 & 26.50 & 46.60 & 48.20 & 62.60 & 22.90 & 4.03 & 6.36 \\
\hline Mean number of holothuroids & 2.33 & 0.33 & 0.50 & 2.83 & 7.67 & 2.50 & 22.67 & 3.33 & 1.67 \\
\hline Mean number of ophiurouds & 0.00 & 0.00 & 4.44 & 18.67 & 1.67 & 2.33 & 1.33 & 0.00 & 0.00 \\
\hline Mean number of bivalves & 0.00 & 100.67 & 521.44 & 1061.89 & 3.33 & 127.00 & 39.67 & 1.00 & 3.00 \\
\hline Mean number of gastropods & 0.00 & 22.67 & 15.28 & 102.17 & 0.67 & 89.00 & 2.00 & 0.00 & 0.33 \\
\hline Mean number of errantiate polychaetes & 4.67 & 19.33 & 45.83 & 56.83 & 14.67 & 31.67 & 36.33 & 7.66 & 6.00 \\
\hline Mean number of sedentariate polychaetes & 3.00 & 72.00 & 197.67 & 638.06 & 36.00 & 91.67 & 104.67 & 57.00 & 14.00 \\
\hline Mean number of crustaceans & 0.00 & 8.67 & 1.83 & 78.72 & 3.00 & 279.00 & 15.33 & 1.00 & 1.30 \\
\hline
\end{tabular}

+ this value is estimated (see results)

* surface sediment core layers - 1-2 cm 
Table 4. Pearson correlation coefficients between biotic and sediment factors for core/grab data for AMP locations from the Strait of Georgia; \%polychaetes is proportion of abundance made up of all polychaetes; \%bivalves is proportion of abundance made up of bivalves. All biotic factors are values per grab $\left(=0.1 \mathrm{~m}^{2}\right)$. All values were exploratory only, without any hypothesis testing. For reference, values $>0.755$ would be considered significant at $p=0.05$ for testing the null hypothesis that the correlation coefficient was 0 for any given correlation.

\begin{tabular}{|c|c|c|c|c|c|c|c|c|c|c|c|c|}
\hline \multirow{3}{*}{$\begin{array}{l}\text { Sedimentation rate }\left(\mathrm{g}^{\wedge} \mathrm{cm}^{-}\right. \\
\left.{ }^{2} \mathrm{yr}\right) \\
\text { Organic carbon flux ( } \mathrm{mg} \\
\left.\mathrm{C}^{\wedge} \mathrm{cm}^{-2} \mathrm{yr}\right)\end{array}$} & $\begin{array}{l}\text { Number } \\
\text { of Taxa }\end{array}$ & $\begin{array}{l}\text { Total } \\
\text { Faunal } \\
\text { Abundance }\end{array}$ & $\begin{array}{l}\text { Biomass } \\
(\mathrm{g})\end{array}$ & $\begin{array}{l}\text { Number of } \\
\text { holothuroids }\end{array}$ & $\begin{array}{l}\text { Number of } \\
\text { ophiuroids }\end{array}$ & $\begin{array}{l}\text { Number of } \\
\text { bivalves }\end{array}$ & $\begin{array}{l}\text { Number of } \\
\text { gastropds }\end{array}$ & $\begin{array}{l}\text { Number of } \\
\text { errantiate } \\
\text { polychatesr }\end{array}$ & $\begin{array}{l}\text { Number of } \\
\text { sedentariate } \\
\text { polychaetes }\end{array}$ & $\begin{array}{l}\text { Number of } \\
\text { crustaceans }\end{array}$ & $\begin{array}{l}\% \\
\text { polychaetes }\end{array}$ & $\begin{array}{l}\% \\
\text { bivalve }\end{array}$ \\
\hline & 0.74 & 0.92 & 0.85 & -0.20 & 0.86 & 0.83 & 0.94 & 0.78 & 0.84 & 0.64 & -0.45 & 0.7 \\
\hline & 0.71 & 0.90 & 0.87 & -0.27 & 0.73 & 0.75 & 0.92 & 0.76 & 0.72 & 0.73 & -0.58 & 0.6 \\
\hline \multirow{3}{*}{ 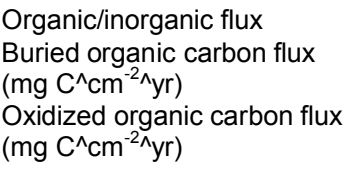 } & -0.90 & -0.63 & -0.66 & -0.35 & -0.45 & -0.47 & -0.51 & -0.76 & -0.54 & -0.35 & 0.51 & -0.5 \\
\hline & 0.69 & 0.86 & 0.89 & -0.19 & 0.80 & 0.74 & 0.94 & 0.71 & 0.76 & 0.72 & -0.46 & 0.5 \\
\hline & 0.47 & 0.63 & 0.46 & -0.38 & 0.20 & 0.46 & 0.45 & 0.58 & 0.27 & 0.46 & -0.68 & 0.5 \\
\hline \multirow{2}{*}{$\begin{array}{l}\text { Water depth of sample }(\mathrm{m}) \\
\% \mathrm{TN}^{*}\end{array}$} & -0.53 & -0.66 & -0.13 & 0.29 & -0.45 & -0.63 & -0.50 & -0.62 & -0.52 & -0.18 & 0.65 & -0.7 \\
\hline & -0.92 & -0.67 & -0.62 & -0.24 & -0.46 & -0.53 & -0.49 & -0.80 & -0.56 & -0.29 & 0.54 & -0.6 \\
\hline \multirow{2}{*}{$\begin{array}{l}\text { \%Carbonate* } \\
\text { \%TOC* }\end{array}$} & 0.85 & 0.93 & 0.60 & -0.10 & 0.85 & 0.94 & 0.63 & 0.92 & 0.91 & 0.16 & -0.35 & 0.9 \\
\hline & -0.92 & -0.66 & -0.64 & -0.29 & -0.45 & -0.51 & -0.49 & -0.79 & -0.54 & -0.32 & 0.54 & -0.6 \\
\hline \multirow{2}{*}{$\begin{array}{l}\% \mathrm{TOC} / \% \mathrm{TN}^{*} \\
\delta^{15} \mathrm{~N}^{*}\end{array}$} & 0.58 & 0.62 & 0.22 & -0.39 & 0.58 & 0.70 & 0.42 & 0.55 & 0.64 & -0.07 & -0.35 & 0.8 \\
\hline & -0.74 & -0.80 & -0.39 & 0.16 & -0.56 & -0.79 & -0.40 & -0.84 & -0.66 & -0.03 & 0.61 & -0.9 \\
\hline \multirow{3}{*}{$\begin{array}{l}\delta^{13} \mathrm{C}^{*} \\
\text { Organic carbon flux } / \delta^{15} \mathrm{~N} \\
\text { Acid -volatile sulphides } \\
\text { (umol/g) }\end{array}$} & -0.79 & -0.74 & -0.40 & 0.03 & -0.64 & -0.77 & -0.39 & -0.81 & -0.72 & 0.06 & 0.54 & -0.8 \\
\hline & 0.71 & 0.96 & $\begin{array}{r}0.69 \\
\end{array}$ & -0.31 & 0.78 & 0.90 & 0.73 & 0.86 & 0.81 & 0.41 & -0.52 & 0.8 \\
\hline & -0.04 & 0.06 & -0.23 & -0.40 & -0.07 & 0.21 & -0.20 & 0.26 & -0.02 & -0.21 & -0.36 & 0.6 \\
\hline
\end{tabular}

